\title{
California State Waters Map Series-Offshore of Aptos, California
}

By Guy R. Cochrane, Samuel Y. Johnson, Peter Dartnell, H. Gary Greene, Mercedes D. Erdey, Bryan E. Dieter, Nadine E. Golden, Stephen R. Hartwell, Andrew C. Ritchie, Rikk G. Kvitek, Katherine L. Maier, Charles A. Endris, Clifton W. Davenport, Janet T. Watt, Ray W. Sliter, David P. Finlayson, and Lisa M. Krigsman

(Guy R. Cochrane and Susan A. Cochran, editors)

Pamphlet to accompany

Open-File Report 2016-1025

2016

U.S. Department of the Interior

U.S. Geological Survey 


\section{U.S. Department of the Interior \\ SALLY JEWELL, Secretary}

\section{U.S. Geological Survey \\ Suzette M. Kimball, Director}

U.S. Geological Survey, Reston, Virginia: 2016

For more information on the USGS—-the Federal source for science about the Earth, its natural and living resources, natural hazards, and the environment-visit

http://www.usgs.gov/ or call 1-888-ASK-USGS (1-888-275-8747).

For an overview of USGS information products, including maps, imagery, and publications, visit http://www.usgs.gov/pubprod/.

To order USGS information products, visit http://store.usgs.gov/.

Any use of trade, firm, or product names is for descriptive purposes only and does not imply endorsement by the U.S. Government.

Although this information product, for the most part, is in the public domain, it also may contain copyrighted materials as noted in the text. Permission to reproduce copyrighted items must be secured from the copyright owner.

Suggested citation:

Cochrane, G.R., Johnson, S.Y., Dartnell, P., Greene, H.G., Erdey, M.D., Dieter, B.E., Golden, N.E., Hartwell, S.R., Ritchie, A.C., Kvitek, R.G., Maier, K.L., Endris, C.A., Davenport, C.W., Watt, J.T., Sliter, R.W., Finlayson, D.P., and Krigsman, L.M. (G.R. Cochrane and S.A. Cochran, eds.), 2016, California State Waters Map Series-Offshore of Aptos, California: U.S. Geological Survey Open-File Report 2016-1025, pamphlet 43 p., 10 sheets, scale 1:24,000, http://dx.doi.org/10.3133/ofr20161025.

ISSN 2331-1258 (online) 


\section{Contents}

Preface

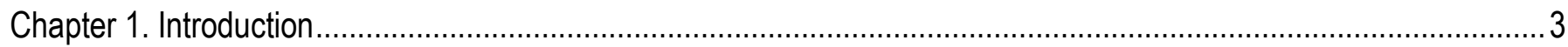

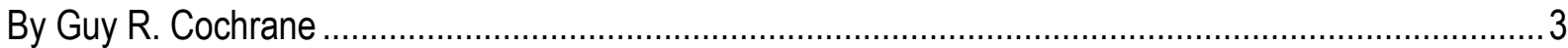

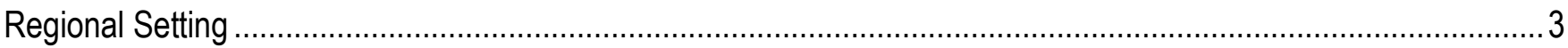

Publication Summary .......................................................................................................................

Chapter 2. Bathymetry and Backscatter-Intensity Maps for the Offshore of Aptos Map Area (Sheets 1, 2, and 3) .......8

By Peter Dartnell and Rikk G. Kvitek

Chapter 3. Data Integration and Visualization for the Offshore of Aptos Map Area (Sheet 4) ..................................... 10

By Peter Dartnell

Chapter 4. Seafloor-Character Map of the Offshore of Aptos Map Area (Sheet 5) ..................................................11

By Mercedes D. Erdey and Guy R. Cochrane

Chapter 5. Ground-Truth Studies for Offshore of Aptos Map Area (Sheet 6) ..........................................................17

By Nadine E. Golden and Guy R. Cochrane

Chapter 6. Potential Marine Benthic Habitat of the Offshore of Aptos Map Area (Sheet 7) ........................................2 20

By H. Gary Greene and Charles A. Endris

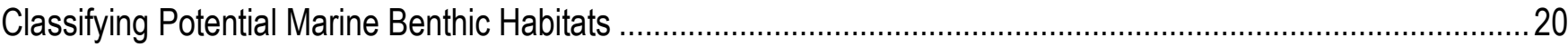

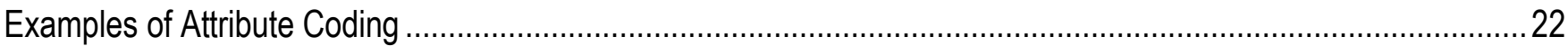

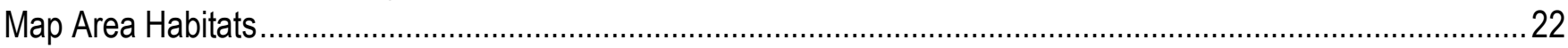

Chapter 7. Subsurface Geology and Structure of the Offshore of Aptos Map Area and the Pigeon Point to Southern

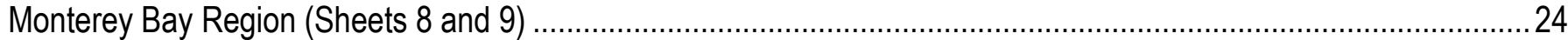

By Samuel Y. Johnson, Stephen R. Hartwell, Janet T. Watt, and Katherine L. Maier

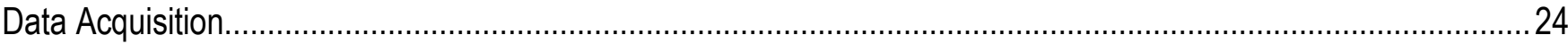

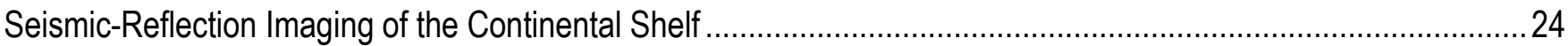

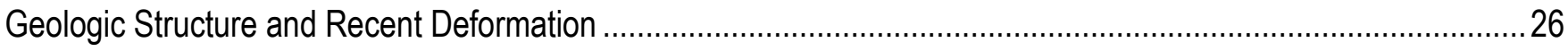

Thickness and Depth to Base of Uppermost Pleistocene and Holocene Deposits ...............................................26

Chapter 8. Geologic and Geomorphic Map of the Offshore of Aptos Map Area (Sheet 10) ........................................ 30

By Samuel Y. Johnson, Stephen R. Hartwell, Clifton W. Davenport, and Katherine L. Maier

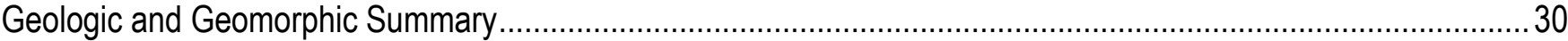

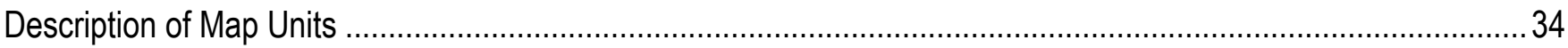

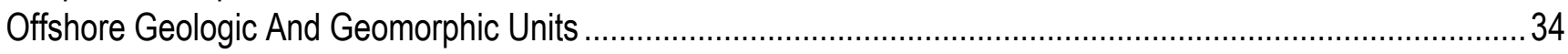

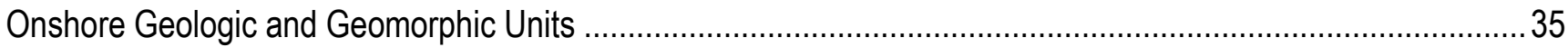

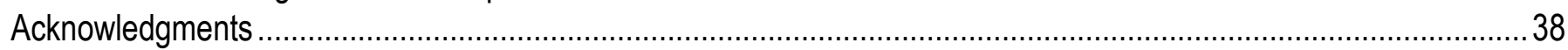

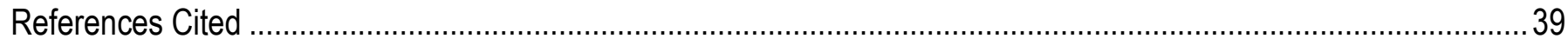

\section{Figures}

Figure 1-1. Physiography of Pigeon Point to southern Monterey Bay region and its environs ................................... 6

Figure 1-2. Coastal geography of Offshore of Aptos map area.......................................................................

Figure 4-1. Detailed view of ground-truth data, showing accuracy-assessment methodology .................................. 14

Figure 5-1. Photograph of USGS camera sled being prepared to be launched off ship for ground-truth survey......... 17

Figure 5-2. Graph showing the distribution of primary and secondary substrate determined from video observations in the Offshore of Aptos map area 


\section{Tables}

Table 4-1. Conversion table showing how video observations of primary substrate, secondary substrate, and abiotic seafloor complexity are grouped into seafloor-character-map Classes I, II, and III for use in supervised classification and accuracy assessment in Offshore of Aptos map area

Table 4-2. Accuracy-assessment statistics for seafloor-character-map classifications in Offshore of Aptos map area.

Table 7-1. Area, sediment-thickness, and sediment-volume data for California's State Waters in the Pigeon Point to southern Monterey Bay region (domains 1-6), as well as in Offshore of Aptos map area

Table 8-1. Areas and relative proportions of offshore geologic map units in Offshore of Aptos map area. 33

\section{Map Sheets}

Sheet 1. Colored Shaded-Relief Bathymetry, Offshore of Aptos Map Area, California By Peter Dartnell, Andrew C. Ritchie, David P. Finlayson, and Rikk G. Kvitek

Sheet 2. Shaded-Relief Bathymetry, Offshore of Aptos Map Area, California

By Peter Dartnell, Andrew C. Ritchie, David P. Finlayson, and Rikk G. Kvitek

Sheet 3. Acoustic Backscatter, Offshore of Aptos Map Area, California

By Peter Dartnell, Andrew C. Ritchie, David P. Finlayson, and Rikk G. Kvitek

Sheet 4. Data Integration and Visualization, Offshore of Aptos Map Area, California

By Peter Dartnell

Sheet 5. Seafloor Character, Offshore of Aptos Map Area, California

By Mercedes D. Erdey and Guy R. Cochrane

Sheet 6. Ground-Truth Studies, Offshore of Aptos Map Area, California

By Nadine E. Golden, Guy R. Cochrane, and Lisa M. Krigsman

Sheet 7. Potential Marine Benthic Habitats, Offshore of Aptos Map Area, California

By Bryan E. Dieter, Charles A. Endris, H. Gary Greene, and Mercedes D. Erdey

Sheet 8. Seismic-Reflection Profiles, Offshore of Aptos Map Area, California

By Samuel Y. Johnson, Stephen R. Hartwell, and Ray W. Sliter

Sheet 9. Local (Offshore of Aptos Map Area) and Regional (Offshore from Pigeon Point to Southern Monterey

Bay) Shallow-Subsurface Geology and Structure, California

By Samuel Y. Johnson, Stephen R. Hartwell, Janet T. Watt, Ray W. Sliter, and Katherine L. Maier

Sheet 10. Offshore and Onshore Geology and Geomorphology, Offshore of Aptos Map Area, California

By Samuel Y. Johnson, Stephen R. Hartwell, Clifton W. Davenport, and Katherine L. Maier 


\section{California State Waters Map Series-Offshore of Aptos, California}

By Guy R. Cochrane, ${ }^{1}$ Samuel Y. Johnson, ${ }^{1}$ Peter Dartnell, ${ }^{1}$ H. Gary Greene, ${ }^{2}$ Mercedes D. Erdey, ${ }^{1}$ Bryan E. Dieter, ${ }^{2}$ Nadine E. Golden, ${ }^{1}$ Stephen R. Hartwell, ${ }^{1}$ Andrew C. Ritchie, ${ }^{1}$ Rikk G. Kvitek, ${ }^{3}$ Katherine L. Maier, ${ }^{1}$ Charles A. Endris, ${ }^{2}$ Clifton W. Davenport, ${ }^{4}$ Janet T. Watt, ${ }^{1}$ Ray W. Sliter, ${ }^{1}$ David P. Finlayson, ${ }^{1}$ and Lisa M. Krigsman ${ }^{5}$

(Guy R. Cochrane ${ }^{1}$ and Susan A. Cochran, ${ }^{1}$ editors)

\section{Preface}

In 2007, the California Ocean Protection Council initiated the California Seafloor Mapping Program (CSMP), designed to create a comprehensive seafloor map of high-resolution bathymetry, marine benthic habitats, and geology within California's State Waters. The program supports a large number of coastal-zone- and ocean-management issues, including the California Marine Life Protection Act (MLPA) (California Department of Fish and Wildlife, 2008), which requires information about the distribution of ecosystems as part of the design and proposal process for the establishment of Marine Protected Areas. A focus of CSMP is to map California's State Waters with consistent methods at a consistent scale.

The CSMP approach is to create highly detailed seafloor maps through collection, integration, interpretation, and visualization of swath sonar bathymetric data (the undersea equivalent of satellite remote-sensing data in terrestrial mapping), acoustic backscatter, seafloor video, seafloor photography, high-resolution seismic-reflection profiles, and bottom-sediment sampling data. The map products display seafloor morphology and character, identify potential marine benthic habitats, and illustrate both the surficial seafloor geology and shallow subsurface geology. It is emphasized that the more interpretive habitat and geology maps rely on the integration of multiple, new high-resolution datasets and that mapping at small scales would not be possible without such data.

This approach and CSMP planning is based in part on recommendations of the Marine Mapping Planning Workshop (Kvitek and others, 2006), attended by coastal and marine managers and scientists from around the state. That workshop established geographic priorities for a coastal mapping project and identified the need for coverage of "lands" from the shore strand line (defined as Mean Higher High Water; MHHW) out to the limit of California's State Waters. Unfortunately, surveying the zone from MHHW out to 10-m water depth is not consistently possible using ship-based surveying methods, owing to sea state (for example, waves, wind, or currents), kelp coverage, and shallow rock outcrops.

Accordingly, some of the maps presented in this series commonly do not cover the zone from the shore out to 10-m depth; these "no data" zones appear pale gray on most maps.

This map is part of a series of online U.S. Geological Survey (USGS) publications, each of which includes several map sheets, some explanatory text, and a descriptive pamphlet. Each map sheet

\footnotetext{
${ }^{1}$ U.S. Geological Survey

${ }^{2}$ Moss Landing Marine Laboratories, Center for Habitat Studies

${ }^{3}$ California State University, Monterey Bay, Seafloor Mapping Lab

${ }^{4}$ California Geological Survey

${ }^{5}$ National Oceanic and Atmospheric Administration, National Marine Fisheries Service
} 
is published as a PDF file. Geographic information system (GIS) files that contain both Esri ${ }^{6}$ ArcGIS raster grids (for example, bathymetry, seafloor character) and geotiffs (for example, shaded relief) are also included for each publication. For those who do not own the full suite of Esri GIS and mapping software, the data can be read using Esri ArcReader, a free viewer that is available at http://www.esri.com/software/arcgis/arcreader/index.html (last accessed March 5, 2014).

The California Seafloor Mapping Program (CSMP) is a collaborative venture between numerous different federal and state agencies, academia, and the private sector. CSMP partners include the California Coastal Conservancy, the California Ocean Protection Council, the California Department of Fish and Wildlife, the California Geological Survey, California State University at Monterey Bay's Seafloor Mapping Lab, Moss Landing Marine Laboratories Center for Habitat Studies, Fugro Pelagos, Pacific Gas and Electric Company, National Oceanic and Atmospheric Administration (NOAA, including National Ocean Service - Office of Coast Surveys, National Marine Sanctuaries, and National Marine Fisheries Service), U.S. Army Corps of Engineers, the Bureau of Ocean Energy Management, the National Park Service, and the U.S. Geological Survey.

${ }^{6}$ Environmental Systems Research Institute, Inc. 


\title{
Chapter 1. Introduction
}

\author{
By Guy R. Cochrane
}

\section{Regional Setting}

The map area offshore of Aptos, California, which is referred to herein as the "Offshore of Aptos" map area (fig. 1-1), is located on the Pacific Coast, on the north side of Monterey Bay, about $105 \mathrm{~km}$ southeast of San Francisco. The largest incorporated city in the map area, Capitola, and numerous unincorporated towns including Aptos, lie on uplifted marine terraces between the shoreline, and the northwest-trending Santa Cruz Mountains (figs. 1-1, 1-2), part of California's Coast Ranges. The 2010 U.S. Census Bureau estimated populations of about 6,000 and 10,000 for Aptos and Capitola, respectively. The local economy is based largely on tourism and retail, and Capitola is deemed the oldest beach resort on the U.S. west coast. The map area includes the northernmost part of Santa Cruz Harbor, and Moss Landing Harbor is located about $10 \mathrm{~km}$ south of the map area. The offshore part of the map area is entirely within California's State Waters and is also part of the Monterey Bay National Marine Sanctuary. In the southern part of the map area, the Soquel Canyon State Marine Conservation Area extends eastward from the limit of California's State Waters across Soquel Canyon (fig. 1-2).

The Offshore of Aptos map area is on the western margin of North American Plate - the only continental margin in the world delineated largely by transform faults. The San Andreas Fault Zone (Dickinson, 2004), the most continuous and prominent plate-boundary structure, cuts through the Santa Cruz Mountains just $3.5 \mathrm{~km}$ northeast of the map area (fig. 1-1). The San Gregorio Fault Zone, another major plate-boundary structure, cuts through Monterey Canyon about $13 \mathrm{~km}$ southwest of the map area. Ongoing deformation associated with and between these major fault zones has uplifted the Santa Cruz Mountains and formed well-developed sets of marine terraces that characterize almost the entire coastal zone of the map area (Anderson and Menking, 1994).

The irregular shoreline in the northern part of the map area consists of interspersed cliffs and pocket beaches. Soquel Point (fig. 1-2), locally referred to as "Pleasure Point," is known for world-class surfing. Soquel Point shelters beaches near Capitola from large north and west swells. South of Capitola, the coast is exposed to larger waves and is characterized by an almost continuous sandy beach that includes recreational sites at New Brighton State Beach, Seacliff State Beach, Manresa State Beach, and Sunset State Beach (fig. 1-2).

Coastal sediment in the Offshore of Aptos map area is supplied by coastal watersheds and bluff erosion. Sediment transport in this part of the Santa Cruz littoral cell is primarily from the northwest to the southeast and terminates in the submarine Monterey Canyon (Best and Griggs, 1991; Hapke and others, 2006). Longshore drift is impeded by jetties at Santa Cruz Harbor (fig. 1-2; western edge of map area), resulting in high beach erosion rates east of the harbor (Hapke and others, 2006). Sediment dredged from the harbor mouth (estimated 300,000 $\mathrm{yds}^{3} / \mathrm{yr}$; Griggs and others, 2005) is currently being used to nourish beaches directly to the east. Farther downcoast, the rapidly eroding beach at Capitola was stabilized by construction of an about 75-m-long groin.

The offshore part of the map area consists of relatively flat and shallow continental shelf. The shelf dips gently (less than $1^{\circ}$ ) seaward, so that water depths are predominantly less than $80 \mathrm{~m}$. The shelf is underlain by variable amounts ( 0 to $30 \mathrm{~m}$ ) of upper Quaternary shelf, estuarine, and fluvial sediments deposited as sea level fluctuated in the late Pleistocene. Along the southern edge of the map area, the shelf is incised by the head of Soquel Canyon, a northeast-trending tributary to the west-trending Monterey Canyon (fig. 1-1). During the last sea-level lowstand (the Last Glacial Maximum [LGM], about 21,000 years ago) Soquel Creek flowed through a paleochannel across the emergent shelf into the head of Soquel Canyon. This canyon was disconnected from its onshore watershed during the post-LGM 
sea-level rise of about $125 \mathrm{~m}$; the abandoned paleochannel was subsequently filled with marine sediment.

This part of central California is exposed to large North Pacific swells from the northwest throughout the year. North Pacific swell heights range from 2 to 10 meters, with larger swells occurring from October to May (Storlazzi and Wingfield, 2005). During El Niño-Southern Oscillation (ENSO) events, winter storms track farther south than they do in normal (non-ENSO) years, thereby impacting the map area more frequently and with waves of larger heights (Storlazzi and Wingfield, 2005). Bedrock exposed in coastal cliffs is relatively erosion-resistant, and significant erosional events primarily are restricted to storm-wave activity that also erodes the overlying unconsolidated marine-terrace sediments (Griggs and others, 2005).

Seafloor habitats in the Offshore of Aptos map area lie within the "Shelf" Megahabitat class of Greene and others (1999). Patchy rocky habitats are found offshore of Soquel Point (fig. 1-2) in northern Monterey Bay and in the head of Soquel Canyon. Patchy, gravel-rich scour depressions and minor bedrock habitat occur in the predominantly sandy inner shelf south of Aptos. Sandy shelf habitats grade offshore to mud-dominated habitats on the midshelf in deeper water.

Benthic species observed in the Offshore of Aptos map area are natives of the cold-temperate biogeographic zone that is called either the "Oregonian" province (Briggs, 1974) or the "northern California ecoregion" (Spalding and others, 2007). This biogeographic province is maintained by the long-term stability of the southward-flowing California Current, the eastern limb of the North Pacific subtropical gyre that flows from southern British Columbia to Baja California. At its midpoint off central California, the California Current transports subarctic surface (0-500 m deep) waters southward, about 150 to 1,300 km from shore (Lynn and Simpson, 1987; Collins and others, 2000). Seasonal northwesterly winds (Inman and Jenkins, 1999) that are, in part, responsible for the California Current, generate coastal upwelling. The south end of the Oregonian province is at Point Conception (about 310 $\mathrm{km}$ southeast of the map area), although its associated phylogeographic group of marine fauna may extend beyond to the area offshore of Los Angeles in southern California (Dawson and others, 2006). The ocean off of central California has experienced a warming over the last 50 years that is driving an ecosystem shift away from the productive subarctic regime towards a depopulated subtropical environment (McGowan and others, 1998).

Biological productivity resulting from coastal upwelling supports populations of Sooty Shearwater (Puffinus griseus), Western Gull (Larus occidentalis), Common Murre (Uria aalge), Cassin's Auklet (Ptychoramphus aleuticus), and many other less populous bird species (Ainley and Hyrenbach, 2010). In addition, an observable recovery of Humpback and Blue Whales (Megaptera novaeangliae and Balaenoptera musculus, respectively) has occurred in the area; both species are dependent on coastal upwelling to provide nutrients (Calambokidis and Barlow, 2004). California sea lions (Zalophus californianus) and Pacific harbor seals (Phoca vitulina) are abundant in the map area. Common bottlenose dolphins (Tursiops truncatus) are often observed very close to shore and in the surf zone. The large extent of exposed inner shelf bedrock supports large forests of "bull kelp" (Nereocystis luetkeana) (Miller and Estes, 1989), which is well adapted for high-wave-energy environments (Koehl and Wainwright, 1977). The kelp beds are the northernmost known habitat for the population of southern sea otters (Tinker and others, 2008). Common fish species found in the kelp beds and rocky reefs include blue rockfish (Sebastes mystinus), black rockfish (Sebastes melanops), olive rockfish (Sebastes serranoides), kelp rockfish (Sebastes atrovirens), gopher rockfish (Sebastes carnatus), blackand-yellow rockfish (Sebastes chrysomelas), painted greenling (Oxylebius pictus), kelp greenling (Hexagrammos decagrammus), and lingcod (Ophiodon elongatus) (Stephens and others, 2006). 


\section{Publication Summary}

This publication about the Offshore of Aptos map area includes ten map sheets that contain explanatory text, in addition to this descriptive pamphlet and a data catalog of geographic information system (GIS) files. Sheets 1, 2, and 3 combine data from three different sidescan-sonar surveys to generate comprehensive high-resolution bathymetry and acoustic-backscatter coverage of the map area. These data reveal a range of physiographic features (highlighted in the perspective views on sheet 4) such as the flat, sediment-covered, inner continental to midcontinental shelf interspersed with tectonically controlled bedrock uplifts, and coarse-grained deltas and sediment lobes associated with coastal watersheds. To validate geological and biological interpretations of the sonar data shown in sheets 1, 2, and 3, the U.S. Geological Survey towed a camera sled over specific offshore locations, collecting both video and photographic imagery; these "ground-truth" surveying data are summarized on sheet 6. Sheet 5 is a "seafloor character" map, which classifies the seafloor on the basis of depth, slope, rugosity (ruggedness), and backscatter intensity and which is further informed by the ground-truthsurvey imagery. Sheet 7 is a map of "potential habitats," which are delineated on the basis of substrate type, geomorphology, seafloor process, or other attributes that may provide a habitat for a specific species or assemblage of organisms. Sheet 8 compiles representative seismic-reflection profiles from the map area, providing information on the subsurface stratigraphy and structure of the map area. Sheet 9 shows the distribution and thickness of young sediment (deposited over the last about 21,000 years, during the most recent sea-level rise) in both the map area and the larger Santa Cruz region (offshore from Pigeon Point to the southern Monterey Bay region), interpreted on the basis of the seismicreflection data. Sheet 10 is a geologic map that merges onshore geologic mapping (compiled from existing maps by the California Geological Survey) and new offshore geologic mapping that is based on integration of high-resolution bathymetry and backscatter imagery (sheets 1, 2, 3), seafloor-sediment and rock samples (Reid and others, 2006), digital camera and video imagery (sheet 6), and highresolution seismic-reflection profiles (sheet 8).

The information provided by the map sheets, pamphlet, and data catalog has a broad range of applications. High-resolution bathymetry, acoustic backscatter, ground-truth-surveying imagery, and habitat mapping all contribute to habitat characterization and ecosystem-based management by providing essential data for delineation of marine protected areas and ecosystem restoration. Many of the maps provide high-resolution baselines that will be critical for monitoring environmental change associated with climate change, coastal development, or other forcings. High-resolution bathymetry is a critical component for modeling coastal flooding caused by storms and tsunamis, as well as inundation associated with longer term sea-level rise. Seismic-reflection and bathymetric data help characterize earthquake and tsunami sources, critical for natural-hazard assessments of coastal zones. Information on sediment distribution and thickness is essential to the understanding of local and regional sediment transport, as well as the development of regional sediment-management plans. In addition, siting of any new offshore infrastructure (for example, pipelines, cables, or renewable-energy facilities) will depend on high-resolution mapping. Finally, this mapping will both stimulate and enable new scientific research and also raise public awareness of, and education about, coastal environments and issues. 


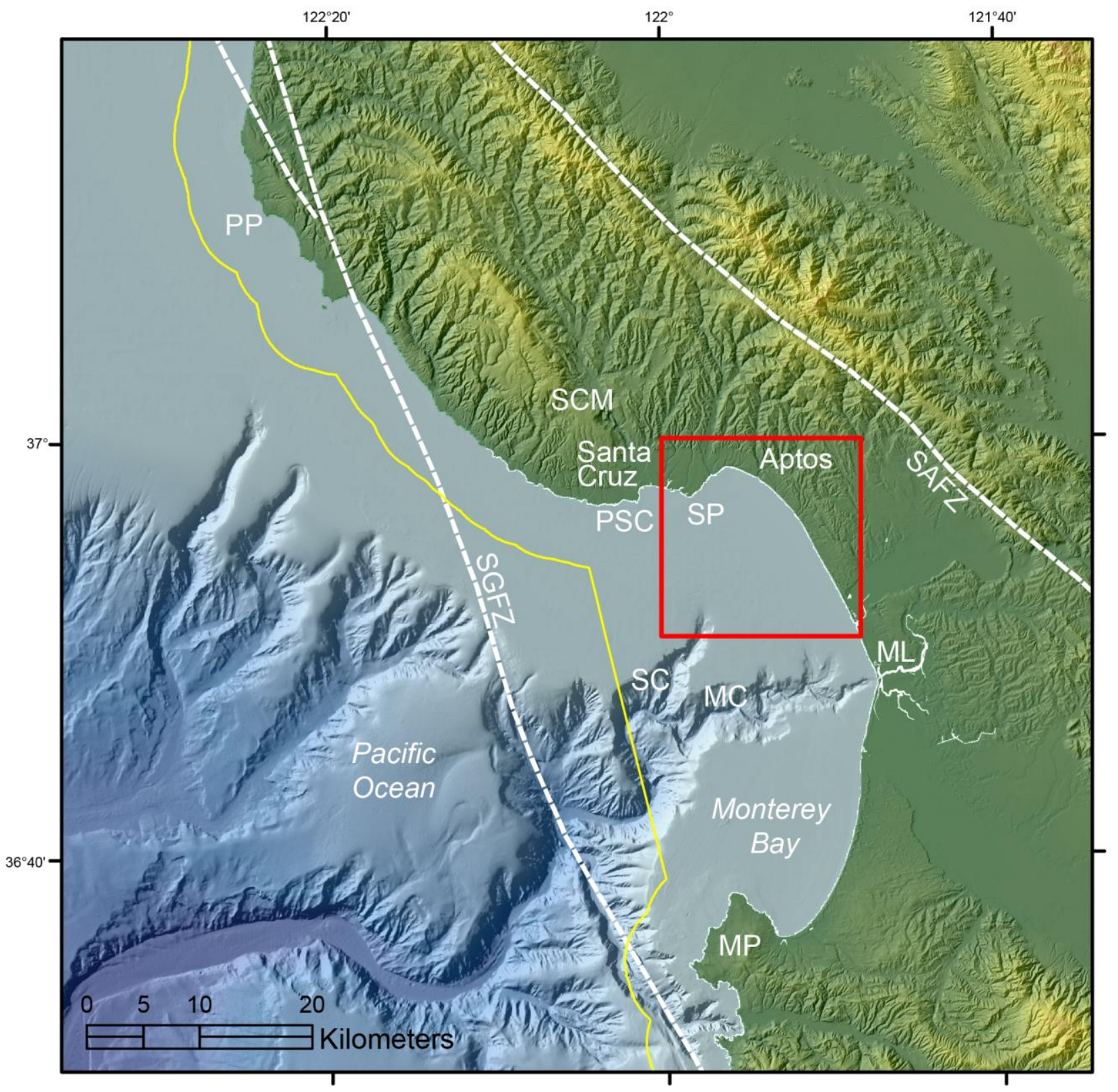

Figure 1-1. Physiography of Pigeon Point to southern Monterey Bay region and its environs. Box shows Offshore of Aptos map area. Yellow line shows limit of California's State Waters. Dashed white lines show traces of San Gregorio Fault Zone (SGFZ) and San Andreas Fault Zone (SAFZ). Other abbreviations: MC, Monterey Canyon; ML, Moss Landing; MP, Monterey peninsula; PP, Pigeon Point; PSC, Point Santa Cruz; SC, Soquel Canyon; SCM, Santa Cruz Mountains; SP, Soquel Point. 


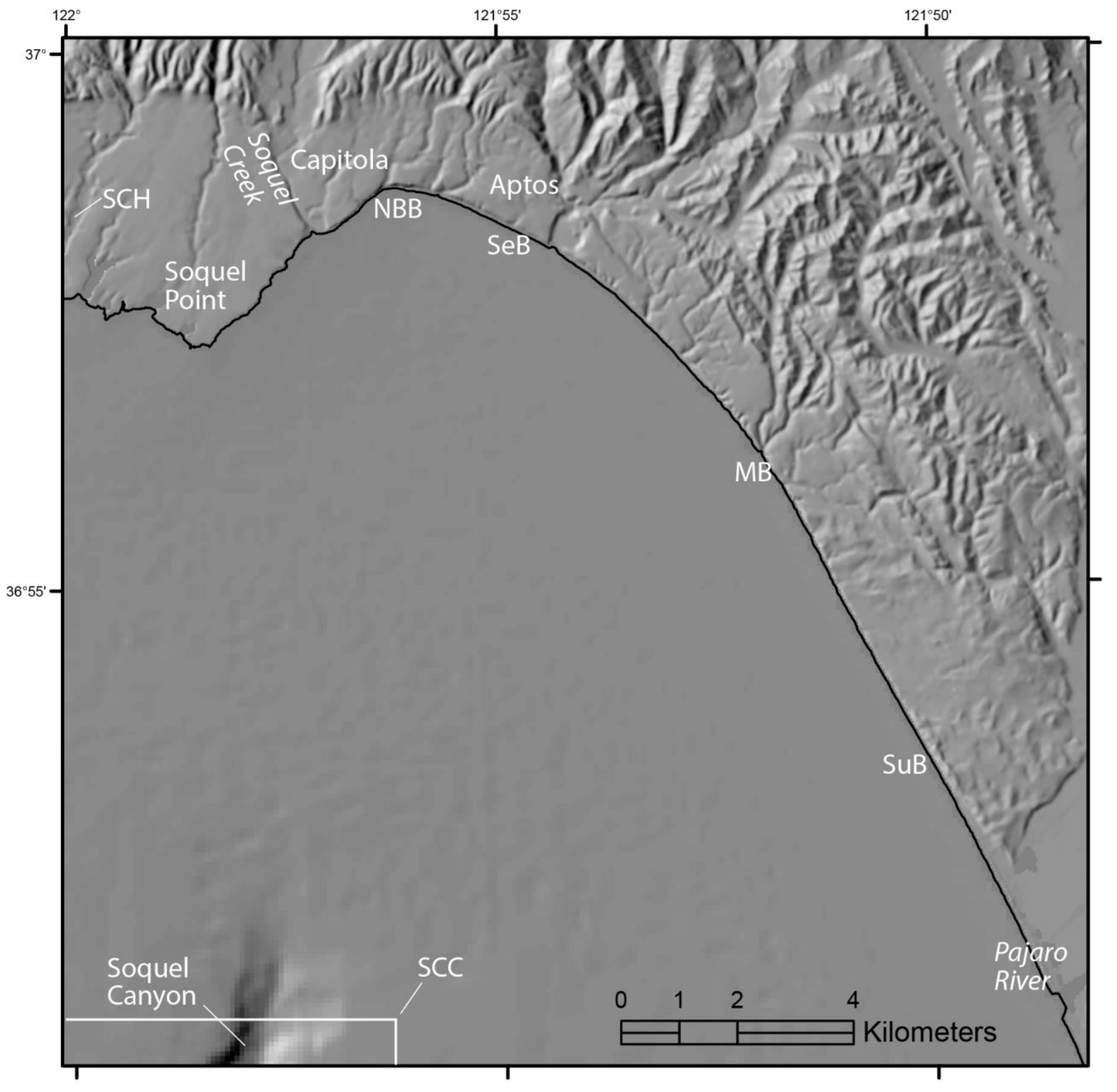

Figure 1-2. Coastal geography of Offshore of Aptos map area. White box outlines Soquel Canyon Marine Conservation Area (SCC). Abbreviations: MB, Manresa State Beach; NBB, New Brighton State Beach; SCH, Santa Cruz Harbor; SeB, Seacliff State Beach; SuB, Sunset State Beach. 


\title{
Chapter 2. Bathymetry and Backscatter-Intensity Maps for the Offshore of Aptos Map Area (Sheets 1, 2, and 3)
}

\author{
By Peter Dartnell and Rikk G. Kvitek
}

The colored shaded-relief bathymetry (sheet 1), the shaded-relief bathymetry (sheet 2), and the acoustic-backscatter (sheet 3) maps of the Offshore of Aptos map area in central California were generated from bathymetry and backscatter data collected by California State University, Monterey Bay (CSUMB), Monterey Bay Aquarium Research Institute (MBARI), and the U.S. Geological Survey (USGS). Mapping was completed in 1998, 2006, and 2009, using a combination of 244-kHz Reson 8101 and 30-kHz Simrad EM-300 multibeam echosounders, as well as a 234-kHz SEA SWATHplus phasedifferencing sidescan-sonar system. The mapping missions collected both bathymetry (sheets 1,2$)$ and acoustic-backscatter data (sheet 3) in all of the Offshore of Aptos map area deeper than $10 \mathrm{~m}$.

During the CSUMB multibeam mapping mission, an Applanix POS MV (Position and Orientation System for Marine Vessels) was used to accurately position the vessel during data collection, and it also accounted for vessel motion such as heave, pitch, and roll (position accuracy, \pm 2 $\mathrm{m}$; pitch, roll, and heading accuracy, $\pm 0.02^{\circ}$; heave accuracy, $\pm 5 \%$, or $5 \mathrm{~cm}$ ). A NavCom 2050 GPS receiver was used to measure tidal-cycle fluctuations; in addition, sound-velocity profiles were collected with an Applied Microsystems (AM) SVPlus sound velocimeter. Soundings were corrected for vessel motion using the Applanix POS MV data, for variations in water-column sound velocity using the AM SVPlus data, and for variations in water height (tides) using vertical-position data from the GPS receivers.

During the MBARI mapping mission an Applied Analytic POS MV was used to accurately position the vessel during data collection and account for vessel motion with navigational input from a kinematic differential global positioning system (DGPS). Soundings were corrected for variations in water-column sound velocity using data from SeaBird CTD (conductivity, temperature, and depth) and Sippican T5 expendable bathythermographs (National Centers for Environmental Information, 2015).

During the USGS mapping mission, GPS data with real-time-kinematic (RTK) corrections were combined with measurements of vessel motion (heave, pitch, and roll) in a CodaOctopus F180 attitudeand-position system to produce a high-precision vessel-attitude packet. This packet was transmitted to the acquisition software in real time and combined with instantaneous sound-velocity measurements at the transducer head before each ping. The returned samples were projected to the seafloor using a raytracing algorithm that works with previously measured sound-velocity profiles. Statistical filters were applied to discriminate seafloor returns (soundings and backscatter intensity) from unintended targets in the water column (Ritchie and others, 2010).

Processed soundings from the different mapping missions were exported from the acquisition or processing software as XYZ files and bathymetric surfaces. All surfaces with similar spatial resolutions were then merged together and clipped to the boundary of the map area. The shallower USGS bathymetric surface has 2-m spatial resolution, while the deeper CSUMB surface has 3-m resolution. An illumination having an azimuth of $300^{\circ}$ and from $45^{\circ}$ above the horizon was then applied to the bathymetric surfaces to create the shaded-relief imagery (sheets 1,2). In addition, a modified "rainbow" color ramp was applied to the bathymetry data for sheet 1 , using reds to represent shallower depths, and purples to represent greater depths. This colored bathymetry surface was draped over the shaded-relief imagery at 60-percent transparency to create a colored shaded-relief map (sheet 1). Ripple patterns and parallel lines that are apparent within the map area are data-collection and -processing artifacts. These artifacts are made obvious by the hillshading process. 
Bathymetric contours (sheets $1,2,3,5,7,10$ ) were generated at 10-m intervals for water depths shallower than $100 \mathrm{~m}$ and at 50-m intervals for water depths deeper than $100 \mathrm{~m}$ from the merged 2-mand 3-m-resolution bathymetric surfaces. The merged surfaces were smoothed using the Focal Mean tool in ArcGIS and a circular neighborhood that has a radius of between 20 and $30 \mathrm{~m}$ (depending on the location). The contours were generated from these smoothed surfaces using the Spatial Analyst Contour tool in ArcGIS. The most continuous contour segments were preserved; smaller segments and isolated island polygons were excluded from the final output. The contours were then clipped to the boundary of the map area.

The SWATHplus backscatter data were post-processed using USGS software (D.P. Finlayson, written commun., 2011) that normalizes for time-varying signal loss and beam-directivity differences. Thus, the raw 16-bit backscatter data were gain-normalized to enhance the backscatter of the SWATHplus system. The resulting normalized-amplitude values were rescaled to 16-bit and gridded into GeoJPEGS using GRID Processor Software, then imported into a GIS and converted to GRIDS.

The 1998 MBARI EM-300 backscatter data covering the head of submarine Soquel Canyon were used in sheet 3. The USGS downloaded the original MBARI survey line files from the National Centers for Environmental Information online bathymetry server (National Centers for Environmental Information, 2015), Using MB-Systems, a freeware software package for processing and displaying backscatter data (Caress and others, 2015), amplitude values were extracted from the lines at 5-m spatial resolution and exported as one XYZ file. The XYZ file was gridded in Fledermaus ${ }^{\circledR}$ software (QPS), converted to an ASCII raster file, and imported into a GIS.

The acoustic-backscatter imagery from each different mapping system and processing method (MBARI and USGS) were merged into their own individual grids. These individual grids, which cover different areas, were displayed in a GIS to create the composite backscatter map (sheet 3). On the map, brighter tones indicate higher backscatter intensity, and darker tones indicate lower backscatter intensity. The intensity represents a complex interaction between the acoustic pulse and the seafloor, as well as characteristics within the shallow subsurface, providing a general indication of seafloor texture and composition. Backscatter intensity depends on the acoustic source level; the frequency used to image the seafloor; the grazing angle; the composition and character of the seafloor, including grain size, water content, bulk density, and seafloor roughness; and some biological cover. Harder and rougher bottom types such as rocky outcrops or coarse sediment typically return stronger intensities (high backscatter, lighter tones), whereas softer bottom types such as fine sediment return weaker intensities (low backscatter, darker tones).

The onshore-area image was generated by applying an illumination having an azimuth of $300^{\circ}$ and from $45^{\circ}$ above the horizon to 2-m-resolution topographic-lidar data from National Oceanic and Atmospheric Administration (NOAA) Office for Coastal Management's Digital Coast (available at http://www.csc.noaa.gov/digitalcoast/data/coastallidar/) and to 10-m-resolution topographic-lidar data from the U.S. Geological Survey's National Elevation Dataset (available at http://ned.usgs.gov/). 


\title{
Chapter 3. Data Integration and Visualization for the Offshore of Aptos Map Area (Sheet 4)
}

\author{
By Peter Dartnell
}

Mapping California's State Waters has produced a vast amount of acoustic and visual data, including bathymetry, acoustic backscatter, seismic-reflection profiles, and seafloor video and photography. These data are used by researchers to develop maps, reports, and other tools to assist in the coastal and marine spatial-planning capability of coastal-zone managers and other stakeholders. For example, seafloor-character (sheet 5), habitat (sheet 7), and geologic (sheet 10) maps of the Offshore of Aptos map area may assist in the designation of Marine Protected Areas. These maps and reports also help to analyze environmental change owing to sea-level rise and coastal development, to model and predict sediment and contaminant budgets and transport, to site offshore infrastructure, and to assess tsunami and earthquake hazards. To facilitate this increased understanding and to assist in product development, it is helpful to integrate the different datasets and then view the results in threedimensional representations such as those displayed on the data integration and visualization sheet for the Offshore of Aptos map area (sheet 4).

The maps and three-dimensional views on sheet 4 were created using a series of geographic information systems (GIS) and visualization techniques. Using GIS, the bathymetric and topographic data (sheet 1) were converted to ASCII raster format files, and the acoustic-backscatter data (sheet 3) were converted to geotiff images. The bathymetric and topographic data were imported in the Fledermaus ${ }^{\circledR}$ software (QPS). The bathymetry was color-coded to closely match the colored shadedrelief bathymetry on sheet 1 , in which reds represent shallower depths and purples represent deeper depths. Acoustic-backscatter geotiff images also were draped over the bathymetry data. The colored bathymetry, topography, and draped backscatter were then tilted and panned to create the perspective views such as those shown in figures $1,2,4,5$ and 6 , on sheet 4 . These views highlight the seafloor morphology in the Offshore of Aptos map area, including complex patterns of ripple scour depressions, a seafloor slump, and the head of submarine Soquel Canyon.

Video-mosaic images created from digital seafloor video (for example, fig. 3 on sheet 4) display the geologic (rock, sand, and mud; see sheet 10) and biologic complexity of the seafloor. Whereas photographs capture high-quality snapshots of smaller areas of the seafloor (see sheet 6), video mosaics capture larger areas and, thus, can show transition zones between seafloor environments. Digital seafloor video is collected from a camera sled towed approximately 1 to 2 meters above the seafloor, at speeds less than 1 nautical mile/hour. Using standard video-editing software, as well as software developed at the Center for Coastal and Ocean Mapping, University of New Hampshire, the digital video is converted to AVI format, cut into 1- to 2-minute sections, and desampled to every second or third frame. The frames are merged together using pattern-recognition algorithms from one frame to the next and converted to a TIFF image. The images are then rectified to the bathymetry data using ship navigation recorded with the video and layback estimates of the towed camera sled.

Block diagrams that combine the bathymetry with seismic-reflection profile data help integrate surface and subsurface observations, especially stratigraphic and structural relations (for example, fig. 2 on sheet 4). These block diagrams were created by converting digital seismic-reflection-profile data into TIFF images, while taking note of the starting and ending coordinates and maximum and minimum depths. The images were then imported into the Fledermaus ${ }^{\circledR}$ software as vertical images and merged with the bathymetry imagery. 


\title{
Chapter 4. Seafloor-Character Map of the Offshore of Aptos Map Area (Sheet 5)
}

\author{
By Mercedes D. Erdey and Guy R. Cochrane
}

The California State Marine Life Protection Act (MLPA) calls for protecting representative types of habitat in different depth zones and environmental conditions. A science team, assembled under the auspices of the California Department of Fish and Wildlife (CDFW), has identified seven substratedefined seafloor habitats in California's State Waters that can be classified using sonar data and seafloor video and photography. These habitats include rocky banks, intertidal zones, sandy or soft ocean bottoms, underwater pinnacles, kelp forests, submarine canyons, and seagrass beds. The following five depth zones, which determine changes in species composition, have been identified: Depth Zone 1, intertidal; Depth Zone 2, intertidal to $30 \mathrm{~m}$; Depth Zone 3, 30 to $100 \mathrm{~m}$; Depth Zone 4, 100 to $200 \mathrm{~m}$; and Depth Zone 5, deeper than $200 \mathrm{~m}$ (California Department of Fish and Wildlife, 2008). The CDFW habitats, with the exception of depth zones, can be considered a subset of a broader classification scheme of Greene and others (1999) that has been used by the U.S. Geological Survey (USGS) (Cochrane and others, 2003, 2005). These seafloor-character maps are generalized polygon shapefiles that have attributes derived from Greene and others (2007).

A 2007 Coastal Map Development Workshop, hosted by the USGS in Menlo Park, California, identified the need for more detailed (relative to Greene and others' [1999] attributes) raster products that preserve some of the transitional character of the seafloor when substrates are mixed and (or) they change gradationally. The seafloor-character map, which delineates a subset of the CDFW habitats, is a geographic information system (GIS)-derived raster product that can be produced in a consistent manner from data of variable quality covering large geographic regions.

The following five substrate classes are identified in the Offshore of Aptos map area:

- Class I: Fine- to medium-grained smooth sediment

- Class II: Mixed smooth sediment and rock

- Class III: Rock and boulder, rugose

- Class IV: Medium- to coarse-grained sediment (in scour depressions)

- Class V: Hard anthropogenic material

The seafloor-character map of the Offshore of Aptos map area (sheet 5) was produced using video-supervised maximum-likelihood classification of the bathymetry and intensity of return from sonar systems, following the method described by Cochrane (2008). The two variants used in this classification were backscatter intensity and derivative rugosity. Rugosity calculation was performed using the Terrain Ruggedness (VRM) tool within the Benthic Terrain Modeler toolset v. 3.0 (Wright and others, 2012; available at http://esriurl.com/5754).

Classes I, II, and III values were delineated using multivariate analysis. Class IV (medium- to coarse-grained sediment, in scour depressions) values were determined on the basis of their visual characteristics using both shaded-relief bathymetry and backscatter (slight depression in the seafloor, very high backscatter return). Class $\mathrm{V}$ (hard anthropogenic material) values were determined on the basis of their visual characteristics and the known location of man-made features. The resulting map (gridded at $2 \mathrm{~m}$ ) was cleaned by hand to remove data-collection artifacts (for example, the trackline nadir).

On the seafloor-character map (sheet 5), the five substrate classes have been colored to indicate the California MLPA depth zones and the Coastal and Marine Ecological Classification Standard 
(CMECS) slope zones (Madden and others, 2008) in which they belong. The California MLPA depth zones are Depth Zone 1 (intertidal), Depth Zone 2 (intertidal to $30 \mathrm{~m}$ ), Depth Zone 3 (30 to $100 \mathrm{~m}$ ), Depth Zone 4 (100 to $200 \mathrm{~m}$ ), and Depth Zone 5 (greater than $200 \mathrm{~m}$ ); in the Offshore of Aptos map area, Depth Zones 2, 3, 4, and 5 are present. The slope classes that represent the CMECS slope zones are Slope Class $1=$ flat $\left(0^{\circ}\right.$ to $\left.5^{\circ}\right)$, Slope Class $2=\operatorname{sloping}\left(5^{\circ}\right.$ to $\left.30^{\circ}\right)$, Slope Class $3=$ steeply sloping $\left(30^{\circ}\right.$ to $\left.60^{\circ}\right)$, Slope Class $4=$ vertical $\left(60^{\circ}\right.$ to $\left.90^{\circ}\right)$, and Slope Class $5=$ overhang (greater than $90^{\circ}$ ); in the Offshore of Aptos map area, only Slope Classes 1 and 2 are present. The final classified seafloorcharacter raster map image has been draped over the shaded-relief bathymetry for the area (sheets 1 and 2) to produce the image shown on the seafloor-character map on sheet 5.

The seafloor-character classification also is summarized on sheet 5 in table 1. Fine- to mediumgrained smooth sediment (sand and mud) makes up 97.2 percent $\left(177.5 \mathrm{~km}^{2}\right)$ of the map area: 55.2 percent $\left(100.9 \mathrm{~km}^{2}\right)$ is in Depth Zone 2, 40.3 percent $\left(73.6 \mathrm{~km}^{2}\right)$ is in Depth Zone 3, 1.4 percent $(2.5$ $\left.\mathrm{km}^{2}\right)$ is in Depth Zone 4, and 0.3 percent $\left(0.5 \mathrm{~km}^{2}\right)$ is in Depth Zone 5. Mixed smooth sediment (sand and gravel) and rock (that is, sediment typically forming a veneer over bedrock, or rock outcrops with little to no relief) make up 1.8 percent $\left(3.4 \mathrm{~km}^{2}\right)$ of the map area: 1.6 percent $\left(3.0 \mathrm{~km}^{2}\right)$ is in Depth Zone 2, less than 0.1 percent $\left(0.1 \mathrm{~km}^{2}\right)$ is in Depth Zone 3, 0.1 percent $\left(0.2 \mathrm{~km}^{2}\right)$ is in Depth Zone 4 , and less than 0.1 percent $\left(0.1 \mathrm{~km}^{2}\right)$ is in Depth Zone 5. Rock and boulder, rugose (rock outcrops and boulder fields having high surficial complexity) makes up 0.4 percent $\left(0.7 \mathrm{~km}^{2}\right)$ of the map area: 0.3 percent $(0.6$ $\left.\mathrm{km}^{2}\right)$ is in Depth Zone 2, less than 0.1 percent $\left(<0.1 \mathrm{~km}^{2}\right)$ is in Depth Zone 3, less than 0.1 percent $(<0.1$ $\left.\mathrm{km}^{2}\right)$ is in Depth Zone 4, and less than 0.1 percent $\left(<0.1 \mathrm{~km}^{2}\right)$ is in Depth Zone 5. Medium- to coarsegrained sediment (in scour depressions consisting of material that is coarser than the surrounding seafloor), which makes up 0.6 percent $\left(1.0 \mathrm{~km}^{2}\right)$ of the map area, is present only in Depth Zone 2 . Rugged, hard anthropogenic material (a pipe), which makes up less than 0.1 percent $\left(<0.1 \mathrm{~km}^{2}\right)$ of the map area, is present only in Depth Zone 2.

A small number of video observations and sediment samples were used to supervise the numerical classification of the seafloor. All video observations (see sheet 6) are used for accuracy assessment of the seafloor-character map after classification. To compare observations to classified pixels, each observation point is assigned a class (I, II, or III), according to the visually derived, major or minor geologic component (for example, sand or rock) and the abiotic complexity (vertical variability) of the substrate recorded during ground-truth surveys (table 4-1; see also, chapter 5 of this pamphlet). Class IV values were assigned on the basis of the observation of one or more of a group of features that includes both larger scale bedforms (for example, sand waves), as well as sediment-filled scour depressions that resemble the "rippled scour depressions" of Cacchione and others (1984) and Phillips and others (2007), and also the "sorted bedforms" of Murray and Thieler (2004), Goff and others (2005), and Trembanis and Hume (2011). On the geologic map (see sheet 10 of this report), they are referred to as "marine shelf scour depressions." Class V values were determined from the visual characteristics and known locations of man-made features.

Next, circular buffer areas were created around individual observation points using a 10-m radius to account for layback and positional inaccuracies inherent to the towed-camera system. The radius length is an average of the distances between the positions of sharp interfaces seen on both the video (the position of the ship at the time of observation) and sonar data, plus the distance covered during a 10-second observation period at an average speed of 1 nautical mile/hour. Each buffer, which covers more than $300 \mathrm{~m}^{2}$, contains approximately 77 pixels. The classified (I, II, III) buffer is used as a mask to extract pixels from the seafloor-character map. These pixels are then compared to the class of the buffer. For example, if the shipboard-video observation is Class II (mixed smooth sediment and rock), but 12 of the 77 pixels within the buffer area are characterized as Class I (fine- to medium-grained smooth sediment), and 15 (of the 77) are characterized as Class III (rock and boulder, rugose), then the comparison would be "Class I, 12; Class II, 50; Class III, 15" (fig. 4-1). If the video observation of 
substrate is Class II, then the classification is accurate because the majority of seafloor pixels in the buffer are Class II. The accuracy values in table 4-2 represent the final of several classification iterations aimed at achieving the best accuracy, given the variable quality of sonar data (see discussion in Cochrane, 2008) and the limited ground-truth information available when compared to the continuous coverage provided by swath sonar. Presence/absence values in table 4-2 reflect the percentages of observations where the sediment classification of at least one pixel within the buffer zone agreed with the observed sediment type at a certain location.

The seafloor in the Offshore of Aptos map area is mainly flat with small sedimentary bedrock exposures (Class III). The seabed is predominantly covered by Class I sediment composed of soft, unconsolidated sand and mud. There are a few exposed, low-relief outcrops of the Purisima Formation (Class III) situated mostly from Aptos to the western edge of the map area. Exposed rock is covered intermittently by varying thicknesses of fine- (Class I) to coarse-grained (Class II) sediment (coarse sand and gravel). The head of the Soquel Canyon (down to $260 \mathrm{~m}$ water depth) is visible near the southwestern boundary of the map. The steeper, more rugose walls of the canyon show exposed outcrops of the Purisima Formation (Class III); the rest of the canyon is covered with a mixture of muddy sediments (Class I) and coarser grained sands and gravels (Class II). A series of small scour depressions (Class IV) are dispersed in the shallow nearshore area (intertidal to $30 \mathrm{~m}$ ) in the northern part of the map area. There is one anthropogenic feature, a wastewater outflow pipeline, near the southern boundary of the map area.

The classification accuracy of Class I (2-m-resolution grid, 94 percent accurate; 5-m-resolution grid, 94 percent accurate; table 4-2) is determined by comparing the shipboard video observations and the classified map. The moderate agreement in Class II (2-m-resolution grid, 51 percent accurate; 5-mresolution grid, 30 percent accurate) and the weak agreement in Class III (2-m-resolution grid, 28 percent accurate; 5-m-resolution grid, 33 percent accurate) likely are due to (1) the distribution of small, localized rock outcrops, (2) the relatively narrow and intermittent nature of transition zones from sediment to rock, and (3) the size of the buffer. The bedrock outcrops in this area are composed of differentially eroded sedimentary rocks (Cochrane and Lafferty, 2002). Erosion of softer layers produces Class I and II sediments, resulting in patchy rugose rock and boulder habitat (Class III) on the seafloor. A single buffered observation locale of 78 pixels, therefore, is likely to be interspersed with other classes of pixels, in addition to Class III. Percentages for presence/absence within a buffer also were calculated as a better measure of the accuracy of the classification for patchy rock habitat. The presence/absence accuracy was found to be significant for all classes with video observations within the coverage of the 2m-resolution seafloor-character map (100 percent for Class I, 94 percent for Class II, and 63 percent for Class III). Presence/absence accuracy also was found to be significant for all classes with video observations within the coverage of the 5-m-resolution seafloor-character map (100 percent for Class I, Class II, and Class III). No video observations or sediment samples were retrieved over Class IV (medium- to coarse-grained sediment in scour depressions) or Class V (rugged, hard anthropogenic feature, pipe) substrate in the seafloor-character map of either resolution; therefore, no accuracy assessments were performed for these classes. 


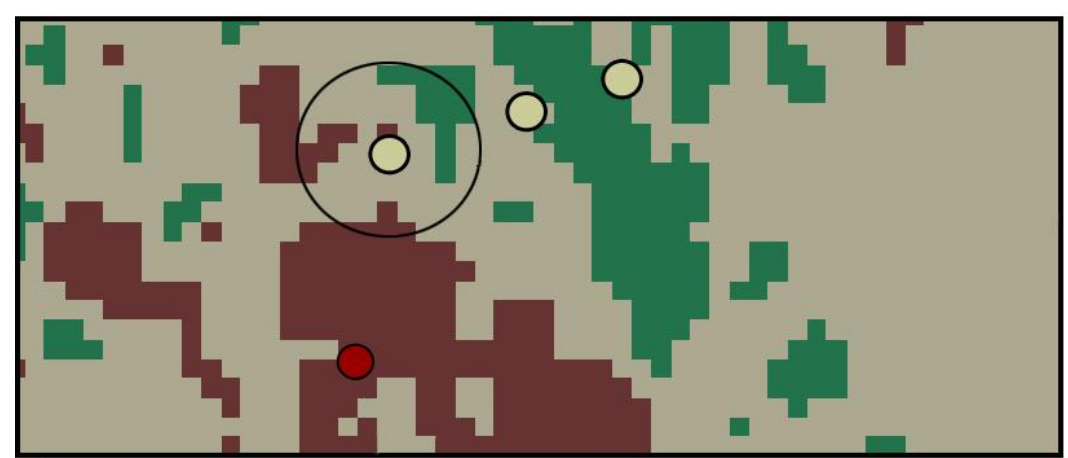

A

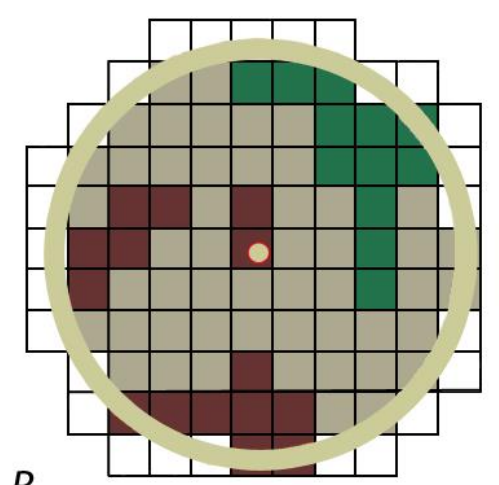

$B$

Figure 4-1. Detailed view of ground-truth data, showing accuracy-assessment methodology. A, Dots illustrate ground-truth observation points, each of which represents 10-second window of substrate observation plotted over seafloor-character grid; circle around dot illustrates area of buffer depicted in $B$. $B$, Pixels of seafloorcharacter data within 10-m-radius buffer centered on one individual ground-truth video observation. 
Table 4-1. Conversion table showing how video observations of primary substrate (more than 50 percent seafloor coverage), secondary substrate (more than 20 percent seafloor coverage), and abiotic seafloor complexity (in first three columns) are grouped into seafloor-character-map Classes I, II, and III for use in supervised classification and accuracy assessment in Offshore of Aptos map area.

[In areas of low visibility where primary and secondary substrate could not be identified with confidence, recorded observations of substrate (in fourth column) were used to assess accuracy]

\begin{tabular}{|c|c|c|c|}
\hline Primary-substrate component & Secondary-substrate component & Abiotic seafloor complexity & $\begin{array}{l}\text { Low-visibility } \\
\text { observations }\end{array}$ \\
\hline \multicolumn{4}{|c|}{ Class I } \\
\hline mud & mud & low & \\
\hline mud & sand & low & \\
\hline sand & mud & low & \\
\hline \multirow[t]{3}{*}{ sand } & sand & low & \\
\hline & & & sediment \\
\hline & & & ripples \\
\hline \multicolumn{4}{|c|}{ Class II } \\
\hline cobbles & sand & moderate & \\
\hline gravel & cobbles & low & \\
\hline gravel & gravel & low & \\
\hline rock & gravel & low & \\
\hline rock & mud & low & \\
\hline rock & sand & low & \\
\hline rock & rock & low & \\
\hline sand & cobbles & low & \\
\hline sand & cobbles & moderate & \\
\hline sand & gravel & low & \\
\hline sand & rock & low & \\
\hline sand & rock & moderate & \\
\hline \multicolumn{4}{|c|}{ Class III } \\
\hline gravel & boulder & moderate & \\
\hline rock & boulders & moderate & \\
\hline rock & gravel & moderate & \\
\hline rock & rock & moderate & \\
\hline rock & sand & moderate & \\
\hline
\end{tabular}


Table 4-1. Accuracy-assessment statistics for seafloor-character-map classifications in Offshore of Aptos map area.

[Accuracy assessments are based on video observations. N/A, no accuracy assessment was conducted]

\begin{tabular}{|c|c|c|c|}
\hline Class & Number of observations & $\%$ majority & $\%$ presence/absence \\
\hline \multicolumn{4}{|c|}{ 2-m-resolution grid } \\
\hline $\begin{array}{l}\text { I-Fine- to medium-grained smooth } \\
\text { sediment }\end{array}$ & 266 & 93.8 & 99.6 \\
\hline II-Mixed smooth sediment and rock & 32 & 51.4 & 93.8 \\
\hline III-Rock and boulder, rugose & 24 & 28.1 & 62.5 \\
\hline $\begin{array}{l}\text { IV-Medium- to coarse-grained } \\
\text { sediment (in scour depressions) }\end{array}$ & 0 & N/A & N/A \\
\hline $\mathrm{V}$-Rugged anthropogenic feature & 0 & N/A & N/A \\
\hline \multicolumn{4}{|c|}{ 5-m-resolution grid } \\
\hline $\begin{array}{l}\text { I-Fine- to medium-grained smooth } \\
\text { sediment }\end{array}$ & 47 & 93.7 & 100.0 \\
\hline II-Mixed smooth sediment and rock & 4 & 30.0 & 100.0 \\
\hline III-Rock and boulder, rugose & 2 & 33.3 & 100.0 \\
\hline $\begin{array}{l}\text { IV-Medium- to coarse-grained } \\
\text { sediment (in scour depressions) }\end{array}$ & 0 & N/A & N/A \\
\hline $\mathrm{V}$-Rugged anthropogenic feature & 0 & N/A & N/A \\
\hline
\end{tabular}




\title{
Chapter 5. Ground-Truth Studies for Offshore of Aptos Map Area (Sheet 6)
}

\author{
By Nadine E. Golden and Guy R. Cochrane
}

To validate the interpretations of sonar data in order to turn it into geologically and biologically useful information, the U.S. Geological Survey (USGS) towed a camera sled (fig. 5-1) over specific locations throughout the Offshore of Aptos map area to collect video and photographic data that would "ground truth" the seafloor. This ground-truth surveying occurred in 2010 and 2012. The camera sled was towed 1 to $2 \mathrm{~m}$ above the seafloor, at speeds of between 1 and 2 nautical miles/hour. Ground-truth surveys in this map area include approximately 8 trackline kilometers of video and 1,387 still photographs, in addition to 487 recorded seafloor observations of abiotic and biotic attributes. A visual estimate of slope also was recorded.

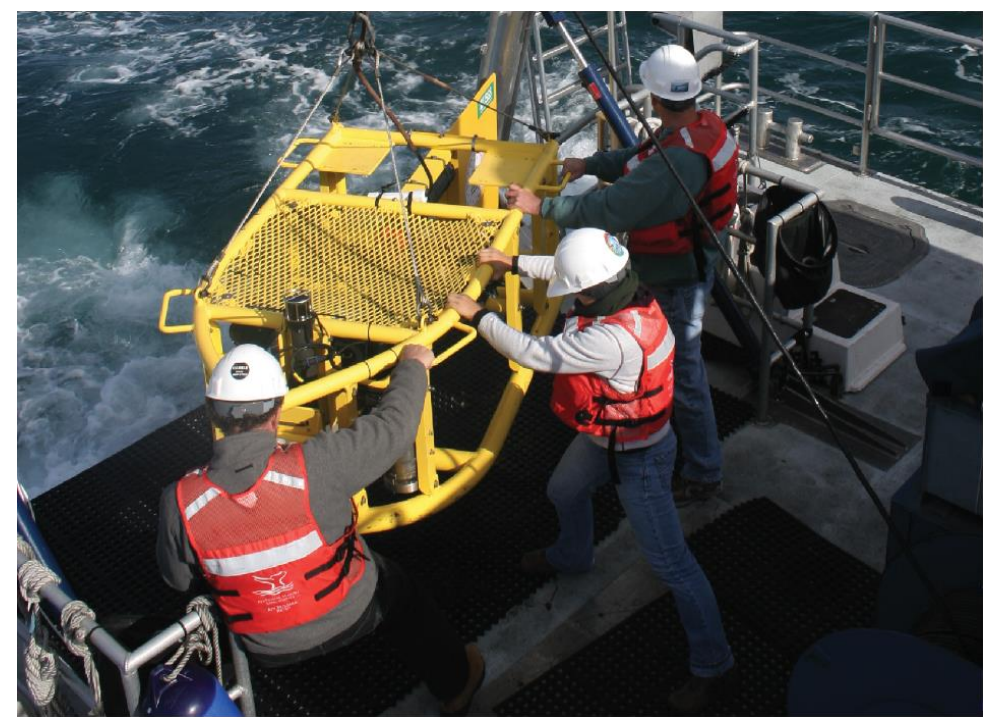

Figure 5-1. Photograph of USGS camera sled being prepared to be launched off ship for ground-truth survey.

During the ground-truth survey cruises, the USGS camera sled housed two standard-definition (640×480 pixel resolution) video cameras (one forward looking, and one downward looking), as well as a high-definition (1,080×1,920 pixel resolution) video camera, and an 8-megapixel digital still camera. During these cruises, in addition to recording the seafloor characteristics, a digital still photograph was captured once every 30 seconds.

The camera-sled tracklines (shown by colored dots on the map on sheet 6) are sited in order to visually inspect areas representative of the full range of bottom hardness and rugosity in the map area. The video is fed in real time to the research vessel, where USGS and National Oceanic and Atmospheric Administration (NOAA) scientists record both the geologic and biologic character of the seafloor. While the camera is deployed, several different observations are recorded for a 10 -second period once every minute, using the protocol of Anderson and others (2007). Observations of primary substrate, secondary substrate, slope, abiotic complexity, biotic complexity, and biotic cover are mandatory. Observations of key geologic features and the presence of key species also are made.

Primary and secondary substrate, by definition, constitute greater than 50 and 20 percent of the seafloor, respectively, during an observation. The grain-size values that differentiate the substrate classes are based on the Wentworth (1922) scale, and the sand, cobble, and boulder sizes are classified 
as in Wentworth (1922). However, the difficulty in distinguishing the finest divisions in the Wentworth (1922) scale during video observations made it necessary to aggregate some grain-size classes, as was done in the Anderson and others (2007) methodology: the granule and pebble sizes have been grouped together into a class called "gravel," and the clay and silt sizes have been grouped together into a class called "mud." In addition, hard bottom and clasts larger than boulder size are classified as "rock." Benthic-habitat complexity, which is divided into abiotic (geologic) and biotic (biologic) components, refers to the visual classification of local geologic features and biota that potentially can provide refuge for both juvenile and adult forms of various species (Tissot and others, 2006).

Sheet 6 contains a smaller, simplified (depth-zone symbology has been removed) version of the seafloor-character map on sheet 5. On this simplified map, the camera-sled tracklines used to groundtruth-survey the sonar data are shown by aligned colored dots, each dot representing the location of a recorded observation. A combination of abiotic attributes (primary- and secondary-substrate compositions), as well as vertical variability, were used to derive the different classes represented on the seafloor-character map (sheet 5); on the simplified map, the derived classes are represented by colored dots. Also on this map are locations of the detailed views of seafloor character, shown by boxes (Boxes A through E); for each view, the box shows the locations (indicated by colored stars) of representative seafloor photographs. For each photograph, an explanation of the observed seafloor characteristics recorded by USGS and NOAA scientists is given. Note that individual photographs often show more substrate types than are reported as the primary and secondary substrate. Organisms, when present, are labeled on the photographs.

The ground-truth survey is designed to investigate areas that represent the full spectrum of highresolution multibeam bathymetry and backscatter-intensity variation. Figure 5-2 shows that the seafloor surface in the Offshore of Aptos map area predominantly consists of sand, mud, and rock. High-relief rocky habitat is found in the nearshore at the northwest end of Monterey Bay; sand and mud habitats dominate in deeper waters, (see also, sheets 5, 7, 9). 
Substrate Distribution for Offshore of Aptos Map Area

Primary Substrate $=\square$ Secondary Substrate $=$

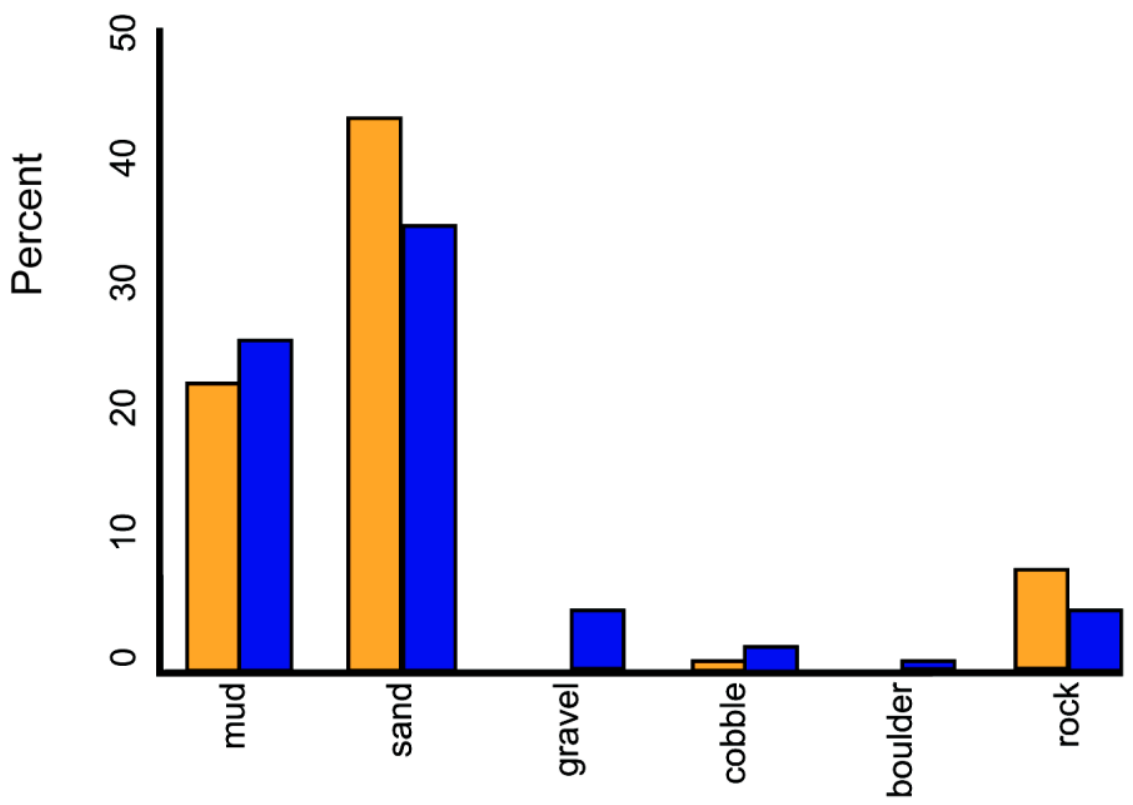

Substrate

Figure 5-2. Graph showing the distribution of primary and secondary substrate determined from video observations in the Offshore of Aptos map area. 


\title{
Chapter 6. Potential Marine Benthic Habitat of the Offshore of Aptos Map Area (Sheet 7)
}

\author{
By H. Gary Greene and Charles A. Endris
}

The map on sheet 7 shows "potential" marine benthic habitats in the Offshore of Aptos Map Area, representing a substrate type, geomorphology, seafloor process, or any other attribute that may provide a habitat for a specific species or assemblage of organisms. This map, which is based largely on seafloor geology, also integrates information displayed on several other thematic maps of the Offshore of Aptos map area. High-resolution sonar bathymetry data, converted to depth grids (seafloor DEMs; sheet 1), are essential to development of the potential marine benthic habitat map, as is shaded-relief imagery (sheet 2), which allows visualization of seafloor terrain and provides a foundation for interpretation of submarine landforms.

Backscatter maps (sheet 3) also are essential for developing potential benthic habitat maps. High backscatter is further indication of "hard" bottom, consistent with interpretation as rock or coarse sediment. Low backscatter, indicative of a "soft" bottom, generally indicates a fine sediment environment. Habitat interpretations also are informed by actual seafloor observations from ground-truth surveying (sheet 6), by seafloor-character maps that are based on video-supervised maximum-likelihood classification (sheet 5), and by seafloor-geology maps (sheet 10). The habitat interpretations on sheet 7 are further informed by the usSEABED bottom-sampling compilation of Reid and others (2006).

Broad, generally smooth areas of seafloor that lack sharp and angular edge characteristics are mapped as "sediment;" these areas may be further defined by various sedimentary features (for example, erosional scours and depressions) and (or) depositional features (for example, dunes, mounds, or sand waves). In contrast, many areas of seafloor bedrock exposures are identified by their common sharp edges and high relative relief; these may be contiguous outcrops, isolated parts of outcrop protruding through sediment cover (pinnacles or knobs), or isolated boulders. In many locations, areas within or around a rocky feature appear to be covered by a thin veneer of sediment; these areas are identified on the habitat map as "mixed" induration (that is, containing both rock and sediment). The combination of remotely observed data (for example, high-resolution bathymetry and backscatter, seismic-reflection profiles) and directly observed data (for example, camera transects, sediment samples) translates to higher confidence in the ability to interpret broad areas of the seafloor.

To avoid any possible misunderstanding of the term "habitat," the term "potential habitat" (as defined by Greene and others, 2005) is used herein to describe a set of distinct seafloor conditions that in the future may qualify as an "actual habitat." Once habitat associations of a species are determined, they can be used to create maps that depict actual habitats, which then need to be confirmed by in situ observations, video, and (or) photographic documentation.

\section{Classifying Potential Marine Benthic Habitats}

Potential marine benthic habitats in the Offshore of Aptos map area are mapped using the Benthic Marine Potential Habitat Classification Scheme, a mapping-attribute code developed by Greene and others $(1999,2007)$. This code, which has been used previously in other offshore California areas (see, for example, Greene and others, 2005, 2007), was developed to easily create categories of marine benthic habitats that can then be queried within a geographic information system (GIS) or a database. The code contains several categories that can be subdivided relative to the spatial scale of the data. The following categories can be applied directly to habitat interpretations determined from remote-sensing imagery collected at a scale of tens of kilometers to one meter: Megahabitat, Seafloor Induration, Meso/Macrohabitat, Modifier, Seafloor Slope, Seafloor Complexity, and Geologic Unit. Additional 
categories of Macro/Microhabitat, Seafloor Slope, Seafloor Complexity, and Geologic Attribute can be applied to habitat interpretations determined from seafloor samples, video, still photographs, or direct observations at a scale of 10 meters to a few centimeters. These two scale-dependent groups of categories can be used together, to define a habitat across spatial scales, or separately, to compare largeand small-scale habitat types.

The four categories and their attribute codes that are used in the Offshore of Aptos map area are explained in detail below (note, however, that not all categories may be used in a particular map area, given the study objectives, data availability, or data quality); attribute codes in each category are depicted on the map by the letters and, in some cases, numbers that make up the map-unit symbols:

Megahabitat-Based on depth and general physiographic boundaries; used to distinguish features on a scale of tens of kilometers to kilometers. Depicted on map by capital letter, listed first in map-unit symbol; generalized depth ranges are given below:

$E=$ Estuary (0 to $100 \mathrm{~m})$

$\mathrm{S}=$ Shelf; continental and island shelves (0 to $200 \mathrm{~m}$ )

Seafloor Induration - Refers to substrate hardness. Depicted on map by lower-case letter, listed second in map-unit symbol; may be further subdivided into distinct sediment types, depicted by lowercase letter(s) in parentheses, listed immediately after substrate hardness; multiple attributes listed in general order of relative abundance, separated by slash; queried where inferred:

$\mathrm{h}=$ Hard bottom (for example, rock outcrop or sediment pavement)

$\mathrm{m}=$ Mixed hard and soft bottom (for example, local sediment cover of bedrock)

$\mathrm{S}=$ Soft bottom; sediment cover

(b) $=$ Boulders

(g) $=$ Gravel

$(\mathrm{s})=$ Sand

$(\mathrm{m})=$ Mud, silt, and (or) clay

Meso/Macrohabitat - Related to scale of habitat; consists of seafloor features one kilometer to one meter in size. Depicted on map by lower-case letter and, in some cases, additional lower-case letter in parentheses, listed third in map-unit symbol; multiple attributes separated by slash:

(b) $/ p=$ Pinnacle indistinguishable from boulder

$\mathrm{c}=$ Canyon

$\mathrm{c}(\mathrm{b})=$ Bar within thalweg

$\mathrm{c}(\mathrm{c})=$ Curve or meander within thalweg

$c(f)=$ Fall or chute within thalweg

$\mathrm{c}(\mathrm{h})=$ Canyon head

$\mathrm{c}(\mathrm{m})=$ Canyon mouth

$\mathrm{c}(\mathrm{t})=$ Thalweg

$\mathrm{c}(\mathrm{w})=$ Canyon wall

$\mathrm{d}=$ Deformed, tilted, and (or) folded bedrock; overhang

$\mathrm{e}=$ Exposure; bedrock

$\mathrm{g}=$ Gully; channel

$\mathrm{h}=$ Hole; depression

$\mathrm{m}=$ Mound; linear ridge

$\mathrm{p}=$ Pinnacle; cone

$S=$ Scarp, cliff, fault, or slump scar

$\mathrm{w}=$ Dynamic bedform

Modifier-Describes texture, bedforms, biology, or lithology of seafloor. Depicted on map by lower-case letter, in some cases followed by additional lower-case letter(s) either after a hyphen or in parenthesis (or both), following an underscore; multiple attributes separated by slash: 
$\_$_ Anthropogenic (artificial reef, breakwall, shipwreck, disturbance)

_a-dd $=\quad$ Dredge disturbance

_a-dg $=\quad$ Dredge groove or channel

-a-dm = Dredge mound (disposal)

- a-dp $=\quad$ Dredge pothole

_a-f $=\quad$ Ferry (or other vessel) propeller-wash scour or scar

- $\mathrm{a}-\mathrm{g}=\quad$ Groin, jetty, rip-rap

a-p $=\quad$ Pipeline

a-td $=\quad$ Trawl disturbance

conglomerate)

$\_\mathrm{b}=$ Bimodal (conglomeratic, mixed [gravel, cobbles, and pebbles])

_ $=$ Consolidated sediment (claystone, mudstone, siltstone, sandstone, breccia, or

- $d=$ Differentially eroded

$-f=$ Fracture, joint; faulted

$\mathrm{g}=$ Granite

- $\mathrm{h}=$ Hummocky, irregular relief

$r=$ Ripple (amplitude, greater than $10 \mathrm{~cm}$ )

_ $=$ Scour (current or ice; direction noted)

$u=$ Unconsolidated sediment

\section{Examples of Attribute Coding}

To illustrate how these attribute codes can be used to describe remotely sensed data, the following examples are given:

Ss(s)_u = Soft unconsolidated sediment (sand), on continental shelf.

$\mathrm{Es}(\mathrm{s} / \mathrm{m})$ _r/u = Rippled soft unconsolidated sediment (sand and mud), in estuary.

She_g = Hard rock outcrop (granite), on continental shelf.

\section{Map Area Habitats}

The Offshore of Aptos map area includes the nearshore and the inner continental shelf areas from offshore of the mouth of the Pajaro River to west of Soquel Point (fig. 1-2). Delineated on the map are 20 potential marine benthic habitat types, all on the continental shelf ("Shelf" megahabitat). The meso- and macrohabitats on the continental shelf include soft, unconsolidated sediment (14 habitat types), such as fine sand and mud and also just sand, as well as dynamic features such as mobile sand sheets, sediment waves, and rippled sediment depressions; sediment-draped features in Soquel Canyon including walls, thalwegs, and canyon-margin terraces; and landslide scarps and intra-canyon landslide scarps and deposits. Mixed substrate, comprising soft sand and gravels overlying consolidated sedimentary bedrock, forms 1 habitat type. Hard substrate forms 4 habitat types, including deformed and differentially eroded bedrock, pinnacles and boulders and, within Soquel Canyon, bedrock landslide scarps and relic shoreline faces. Hard anthropogenic material (a pipe) forms 1 habitat type.

Acoustic-backscatter data show that most of the seafloor is overlain by "soft" materials, consistent with the interpretation that unconsolidated sediments dominate the seafloor in the map area. Sedimentary processes are quite active, especially offshore of the area between Aptos and the Pajaro River, and, thus, habitats are highly dynamic, with sediment transport is primarily to the southeast. Exposure of deformed and differentially eroded bedrock is primarily restricted to the northern part of the Offshore of Aptos map area, where it potentially provides good habitat for rockfish (Sebastes spp.).

Of the $183.09 \mathrm{~km}^{2}$ mapped on the continental shelf in the Offshore of Aptos map area, soft, unconsolidated sediment is the dominant habitat type, covering $170.32 \mathrm{~km}^{2}$ (93.0 percent). Mixed hard- 
soft substrate covers $10.77 \mathrm{~km}^{2}$ (5.9 percent), hard rock covers $1.96 \mathrm{~km}^{2}$ (1.1 percent), and anthropogenic material covers $0.04 \mathrm{~km}^{2}$ (0.02 percent). 


\title{
Chapter 7. Subsurface Geology and Structure of the Offshore of Aptos Map Area and the Pigeon Point to Southern Monterey Bay Region (Sheets 8 and 9)
}

\author{
By Samuel Y. Johnson, Stephen R. Hartwell, Janet T. Watt, and Katherine L. Maier
}

The seismic-reflection profiles presented on sheet 8 provide a third dimension-depth beneath the seafloor - to complement the surficial seafloor-mapping data already presented (sheets 1 through 7) for the Offshore of Aptos map area. These data, which are collected at several resolutions, extend to varying depths in the subsurface, depending on the purpose and mode of data acquisition. The seismicreflection profiles (sheet 8 ) provide information on sediment character, distribution, and thickness, as well as potential geologic hazards, including active faults, areas prone to strong ground motion, and tsunamigenic slope failures. The information on faults provides essential input to national and state earthquake-hazard maps and assessments (for example, Petersen and others, 2014).

The maps on sheet 9 show the following interpretations, which are based on the seismicreflection profiles on sheet 8: the thickness of the uppermost sediment unit(s); the depth to base of this uppermost unit; and both the local and regional distribution of faults and earthquake epicenters (data from U.S. Geological Survey and California Geological Survey, 2010; Northern California Earthquake Data Center, 2014).

\section{Data Acquisition}

Most profiles displayed on sheet 8 (figs. 1, 2, 3, 4, 6, 7, 8, 9, 10) were collected in 2009 on U.S. Geological Survey (USGS) cruise S-N1-09-MB. The single-channel seismic-reflection data were acquired using a SIG 2Mille minisparker system that used a 500-J high-voltage electrical discharge fired 2 times per second, which, at normal survey speeds of 4 to 4.5 nautical miles/hour, gives a data trace every 1.0 to $1.5 \mathrm{~m}$ of lateral distance covered. The data were digitally recorded in standard SEG-Y 32bit floating-point format using Triton Subbottom Logger (SBL) software that merges seismic-reflection data with differential GPS-navigation data. After the survey, a short-window $(20 \mathrm{~ms})$ automatic gain control algorithm was applied to the data, along with a 160 - to $1,200-\mathrm{Hz}$ bandpass filter and a heave correction that uses an automatic seafloor-detection window (averaged across $30 \mathrm{~m}$ of lateral distance covered). These data can resolve geologic features a few meters thick (and, hence, are considered "highresolution"), down to subbottom depths of about $400 \mathrm{~m}$.

Figure 5 on sheet 8 shows a migrated, deep-penetration, multichannel seismic-reflection profile collected in 1982 by WesternGeco on cruise W-34-82-MB. This profile and other similar data were collected in many areas offshore of California in the 1970s and 1980s when the areas were considered a frontier for oil and gas exploration. Most of these data have been publicly released and are now archived at the U.S. Geological Survey National Archive of Marine Seismic Surveys (U.S. Geological Survey, 2009). These data were acquired using a large-volume air-gun source that has a frequency range of 3 to $40 \mathrm{~Hz}$ and recorded with a multichannel hydrophone streamer about $2 \mathrm{~km}$ long. Shot spacing was about $30 \mathrm{~m}$. These data can resolve geologic features that are 20 to $30 \mathrm{~m}$ thick, down to subbottom depths of about $4 \mathrm{~km}$.

\section{Seismic-Reflection Imaging of the Continental Shelf}

Map sheet 8 shows seismic-reflection profiles in the Offshore of Aptos map area, providing imagery of the subsurface geology. The offshore part of the map area lies south and southeast of the southwest flank of the Santa Cruz Mountains in northeastern Monterey Bay. This offshore area extends 
from the shoreline across very gently dipping (about $0.2^{\circ}$ to $0.6^{\circ}$ ) continental shelf to water depths of about $70 \mathrm{~m}$. In the southwestern part of the map, the shelf is incised by the north-trending head of Soquel Canyon, which has a maximum depth of $260 \mathrm{~m}$ on the south edge of the map. The shelf is underlain by Neogene bedrock and a variably thick (as much as $32 \mathrm{~m}$ ) upper Quaternary sediment cover (see sheet 9). Bedrock is characterized by folded and faulted, moderate- to high-amplitude, variably continuous, parallel to subparallel reflections (terminology from Mitchum and others, 1977). The contact between the Neogene bedrock and the overlying upper Quaternary sediments is an angular unconformity, commonly marked by minor channeling and an upward change to lower amplitude, more diffuse reflections.

The Pleistocene deposits that overlie Neogene rocks near the mouth of the Pajaro River are imaged by a mix of reflection types (see figs. 7, 10 on sheet 8), inferred to represent different sedimentary facies. Inferred eolian deposits are characterized by low- to moderate-amplitude, continuous, high-frequency, subparallel to parallel reflections with dips as steep as $10^{\circ}$ (note that dips appear steeper in seismic-reflection profiles because of vertical exaggeration and superficially resemble tectonic folds); variably gentle to steep reflections image primary bedding surfaces on paleo sand dunes. Reflections in inferred interstratified fluvial deposits have similar low to moderate amplitudes, but are discontinuous, horizontal to subhorizontal, and have variable frequency. This mixed eolian-fluvial unit has been mapped onshore along the coast in the surface and subsurface as the Pleistocene Aromas Sand (Brabb, 1997; Hanson, 2003). It forms an important local aquifer, as much as $180 \mathrm{~m}$ thick, and extends to depths as much as $240 \mathrm{~m}$ below sea level.

Eustasy was an important control on late Quaternary deposition in the Offshore of Aptos map area. Sea-level fall prior to the Last Glacial Maximum (LGM) about 21,000 years ago led to westward migration of the shoreline and wave-cut platform, and subaerial exposure and incision of the continental shelf. Global sea level was about 120 to $130 \mathrm{~m}$ lower than present during the LGM, at which time all of the northern Monterey Bay shelf was emergent and the western shoreline was near the modern shelf break, about $20 \mathrm{~km}$ west of the map area. The submarine Monterey Canyon system (including Soquel Canyon) formed a major marine embayment in what is now central Monterey Bay and LGM shorelines rimmed the canyon on both its southern and northern flanks (sheet 10). During the LGM, Soquel Creek flowed through a paleochannel across the emergent shelf into the head of Soquel Canyon (Map B on sheet 9).

The post-LGM rise in sea level was rapid (about 9 to 11 meters per thousand years) until about 7,000 years ago, when it slowed considerably to about $1 \mathrm{~m}$ per thousand years (Stanford and others, 2011). Post-LGM sea-level rise led to broadening of the continental shelf, the progressive eastward migration of the shoreline and wave-cut platform, sediment filling of incised channels (sheet 8), and the associated transgressive erosion and deposition.

Two sedimentary units that formed within this dynamic late Quaternary period of sea-level change are recognized and highlighted in the high-resolution seismic-reflection profiles on sheet 8 . The lower unit (pink shading) of the two units is present locally in the western and central (figs. 1, 4, 6, 8) parts of the map area, but is absent in the eastern part (figs. 7, 9, 10). This lower unit notably includes low-amplitude, low-angle $\left(1^{\circ}\right.$ to $\left.3^{\circ}\right)$, offshore-dipping clinoforms (Catuneanu, 2006) that are as thick as $13 \mathrm{~m}$.

The upper unit (blue shading) of the two units typically is characterized by low- to moderateamplitude, continuous to moderately continuous, subparallel reflections. Reflections within this unit are locally obscured by interstitial gas within the sediment, most notably in the Soquel Creek paleochannel leading to the head of Soquel Canyon (see, for example, figs. 3, 4, 8 on sheet 8). This effect has been referred to as "gas blanking," "acoustic turbidity," or "acoustic masking" (Hovland and Judd, 1988; Fader, 1997). The gas scatters or attenuates the acoustic energy, preventing penetration. This upper unit has its apparent maximum thickness (about $27 \mathrm{~m}$ ) in the paleochannel. 
Our preferred hypothesis is that the clinoforms in the lower unit (pink shading in profiles on sheet 8) of the two upper Quaternary units represent a progradational shoreface and deltaic and sequence that formed during the sea-level regression before the LGM, between about 30,000 and 21,000 years ago (Waelbroeck and others, 2002). The upper unit (blue shading in profiles on sheet 8) represents shelf deposits that formed after the LGM, during the sea-level transgression of the last about 21,000 years (Stanford and others, 2011). In this interpretation, the contact between the upper and lower units is a transgressive surface of erosion that formed as the shoreline migrated landward. Alternatively, Grossman and others (2006) suggested that both units were deposited in the last about 21,000 years, during the latest Pleistocene and Holocene sea-level rise. Because these two upper Quaternary units each consist of unconsolidated sediments, we have combined their thicknesses on the thickness maps (Maps B, D) on sheet 9 .

\section{Geologic Structure and Recent Deformation}

The shelf in the Offshore of Aptos map area is cut by a diffuse zone of northwest-striking, steeply dipping to vertical faults identified in high-resolution seismic-reflection profiles on the basis of the abrupt truncation or warping of reflections and (or) the juxtaposition of reflection panels that have differing seismic parameters. Seismic-reflection profiles traverse as many as 13 faults over a distance of $8 \mathrm{~km}$ (see, for example, fig. 3 on sheet 8). Mapped fault lengths in this diffuse zone are typically 2 to 7 $\mathrm{km}$, and the strike of these offshore faults ranges from about $325^{\circ}$ to $350^{\circ}$ from southwest to northeast. Faults in this diffuse zone cut through Neogene bedrock and locally appear to disrupt overlying upper Quaternary sediments, and the presence of warped reflections along some fault strands suggests there may be both vertical and strike-slip offsets. This broad, distributed zone of deformation resembles the northwest-trending Monterey Bay Fault Zone (Greene, 1977, 1990), which occurs about $10 \mathrm{~km}$ farther west in outer Monterey Bay and similarly lacks a lengthy $(>20 \mathrm{~km})$, continuous "master fault." Deformation in both the Monterey Bay Fault Zone and the diffuse zone of faults in the Offshore of Aptos map area is attributable to their location in the 40-km-wide, northward-narrowing structural zone between two major right-lateral strike-slip fault zones - the San Andreas Fault Zone to the east and the San Gregorio Fault Zone to the west (fig. 1-1) (Greene, 1990; Wagner and others, 2002).

Map E on sheet 9 shows the regional pattern of major faults and recorded earthquakes. Fault locations, which have been simplified, are compiled from interpretation of regional multichannel industry seismic-reflection data, from our mapping within California's State Waters (see sheet 10), from Wagner and others (2002), and from the U.S. Geological Survey's Quaternary fault and fold database (U.S. Geological Survey and California Geological Survey, 2010). Earthquake epicenters are from the Northern California Earthquake Data Center (2014), which is maintained by the U.S. Geological Survey and the University of California, Berkeley, Seismological Laboratory; all events of magnitude 2.0 and greater for the time period 1967 through April 2014 are shown. The 1989 Loma Prieta earthquake (M6.9, 10/17/1989), on the San Andreas Fault Zone in the Santa Cruz Mountains (Spudich, 1996), located just $3.8 \mathrm{~km}$ north of the block boundary, is the most significant event in the region. The largest recorded earthquake in the Offshore of Aptos map area (M4.6, 10/18/1989) occurred just one day after the Loma Prieta earthquake about $5 \mathrm{~km}$ northeast of Aptos in the Santa Cruz Mountains.

\section{Thickness and Depth to Base of Uppermost Pleistocene and Holocene Deposits}

Maps on sheet 9 show the interpreted thickness and the depth to base of uppermost Pleistocene and Holocene deposits, both for the Offshore of Aptos map area (Maps A, B) and, to establish regional context, for a larger area that extends from the Pigeon Point area to southern Monterey Bay (Maps C, D). To make these maps, water bottom and depth to base of the uppermost Pleistocene and Holocene sediment layer were mapped from seismic-reflection profiles (see fig. 1 on sheet 9; see also, sheet 8). 
The difference between the two horizons was exported for every shot point as XY coordinates (UTM zone 10) and two-way travel time (TWT). The thickness of the uppermost Pleistocene and Holocene unit (Maps B, D) was determined by applying a sound velocity of $1,600 \mathrm{~m} / \mathrm{sec}$ to the TWT, resulting in thicknesses of as much as $32 \mathrm{~m}$. The thickness points were interpolated to a preliminary continuous surface, overlaid with zero-thickness bedrock outcrops (see sheet 10), and contoured, following the methodology of Wong and others (2012).

Several factors required manual editing of the preliminary sediment-thickness maps to make the final product. The thickness data points are dense along tracklines (about $1 \mathrm{~m}$ apart) and sparse between tracklines (1 km apart), resulting in minor contouring artifacts. To incorporate the effect of a few abrupt thickness changes along and across faults, to remove irregularities from interpolation, and to reflect other geologic information and complexity, minor manual editing of the preliminary thickness contours was undertaken. Contour modifications and regridding were repeated several times to produce the final sediment-thickness maps (Maps B, D). Information for the depth to base of the uppermost Pleistocene and Holocene unit (Maps A, C) was generated by adding the thickness data to water depths determined by multibeam bathymetry (see sheet 1). The Monterey Canyon system (including Soquel Canyon) is excluded from this analysis because the seismic-reflection database is insufficient to map sediment distribution in the extremely variable submarine canyon environment.

The thickness of uppermost Pleistocene and Holocene sediments in the Offshore of Aptos map area ranges from 0 to $32 \mathrm{~m}$ (Map B on sheet 9), and the depth to the unconformity at the base of this unit ranges from less than 10 to more than $100 \mathrm{~m}$ at the head of Soquel Canyon (Map A). Mean sediment thickness for the map area is $7.4 \mathrm{~m}$, and total sediment volume is $1,241 \times 10^{6} \mathrm{~m}^{3}$ (table 7-1).

Much of the inner shelf (water depths of about 10 to $30 \mathrm{~m}$ ) in the Offshore of Aptos map area consists of exposed bedrock or bedrock overlain by only a thin $(<2.5 \mathrm{~m})$ cover of sediment. This sediment-poor shelf is cut by two sediment-filled paleochannels that extend seaward from the mouths of Soquel Creek and the Pajaro River. The paleochannels connect with a west-trending midshelf (water depths of about 35 to $60 \mathrm{~m}$ ) depocenter comprising two oblate sub-depocenters (maximum sediment thicknesses of 29 and $32 \mathrm{~m}$ ) linked by a "neck" of sediment with a thickness of about $16 \mathrm{~m}$ (Maps B, D). The depocenter is centered above and south of an offshore increase in the slope (from about $0.2^{\circ}$ to more than $1.3^{\circ}$ ) of the underlying angular unconformity. The sediment cover progressively thins to the south in deeper water.

The locally occurring lower clinoform-bearing unit (pink shading) forms the lower part of the upper Quaternary sediment cover in the midshelf depocenter and, by itself, is as thick as $15 \mathrm{~m}$ (figs. 1, 4, 6, on sheet 8; fig. 1 on sheet 9). During the LGM, this regressive delta-shoreface complex became emergent and was locally incised by Soquel Creek. During the following sea-level rise, this deltashoreface complex was partly to wholly eroded as the shoreline migrated landward; preservation of this unit occurred primarily in accommodation space above the local change in the slope of the bedrock unconformity, yielding the more gentle, smooth offshore-dipping (about $0.1^{\circ}$ to $0.4^{\circ}$ ) surface of the modern continental shelf. The upper unit (blue shading) occurs across the entire offshore map area (excluding bedrock outcrops), filling paleochannels and draping the transgressive surface of erosion.

Six different informal "domains" of thickness of uppermost Pleistocene to Holocene sediment (see table 7-1) are recognized on the regional sediment-thickness map (Map D on sheet 9), each with its own diverse set of geologic and (or) oceanographic controls. Note that data from within the Monterey Canyon system (including Soquel Canyon), in the southern part of the Pigeon Point to southern Monterey Bay region, were excluded from this analysis because available seismic-reflection data are insufficient to map sediment distribution in this extremely variable environment.

(1) The southern Monterey Bay domain is bounded by the Monterey Bay shoreline on the south and east, the Monterey Canyon on the north, and the limit of California's State Waters on the west. Sediment derived from the Salinas River forms a large, shore-parallel, subaqueous delta (thickness of as 
much as $32 \mathrm{~m}$ ) that progrades across a thinly sediment-mantled bedrock shelf. Small changes in sediment thickness on the shelf are controlled by irregular bedrock relief that is at least partly attributable to the Monterey Bay Fault Zone (Greene, 1990).

(2) The northern Monterey Bay domain is bounded on the south by Monterey Canyon, on the north and east by the Monterey Bay shoreline, and on the west by the limit of California's State Waters. The head of Monterey Canyon extends nearly to the shoreline, and the canyon forms a sediment trap that effectively separates the littoral- and shelf-sediment transport systems of the two (northern and southern) Monterey Bay domains. The northern Monterey Bay domain is characterized by (a) a sediment-poor inner shelf cut by paleochannels of the San Lorenzo River, the Pajaro River, and Soquel Creek; (b) a midshelf depocenter with sediment as thick as $32 \mathrm{~m}$, much of which was deposited in a pre-LGM prograding delta and (or) shoreface complex and was preserved above a decrease in slope on the underlying unconformity; and (c) a midshelf to outer shelf zone in which sediment generally becomes progressively thinner in the offshore direction.

(3) The Davenport shelf domain extends from the northern limit of Monterey Bay northward to the southern margin of the Waddell Creek depocenter (to the north in the Waddell Creek delta domain). The Davenport shelf domain, as well as the three domains farther north, occupy a section of open, wavedominated coast that is exposed to wave energy higher than that of the Monterey Bay domains to the south. The Davenport shelf domain includes the Davenport depocenter, a prominent midshelf, shoreparallel depocenter present between Davenport and Santa Cruz that mostly consists of a lower, preLGM, clinoform-bearing unit of inferred prograding-shoreface origin. Sediment in this depocenter also is preserved in accommodation space linked to an offshore decrease in the slope of the underlying unconformity. Sediment thickness within the Davenport shelf domain decreases to both the northwest and southeast of this depocenter, owing to the presence of elevated bedrock and (or) the related absence of the lower clinoform-bearing unit.

(4) The Waddell Creek delta domain lies offshore of the mouth of the Waddell Creek coastal watershed, and it is connected to it by a submerged channel. The domain is both distinguished and delineated by the significant Waddell Creek depocenter (maximum sediment thickness of $19 \mathrm{~m}$ ), which forms a moundlike delta that consists entirely of inferred post-LGM deposits whose primary source is Waddell Creek. Sediment thins both north and south of this moundlike delta; its preservation is attributed to its semiprotected (from erosive wave energy) location on the south flank of Point Año Nuevo.

(5) The Año Nuevo shelf domain lies offshore of Point Año Nuevo, from just north of Franklin Point on the north to just north of the mouth of Waddell Creek on the south. Bedrock exposures, which locally reach water depths of $45 \mathrm{~m}$, cover a substantial part of this wave-exposed domain; in deeper waters farther offshore, sediment cover is relatively thin. Sediment thickness in this domain appears to be limited both by the lack of sediment supply (because of its distance from large coastal watersheds) and by the presence of uplifted bedrock, which is linked to a local zone of transpression in the San Gregorio Fault Zone (Weber, 1990). The uplift has raised this domain and exposed it to the high wave energy that is characteristic of this area (Storlazzi and Wingfield, 2005).

(6) The Pigeon Point shelf domain lies on the west flank of the Pigeon Point high (McCulloch, 1987). Sediment in the Pigeon Point shelf domain is thickest in a shore-parallel band that overlies a slope break in the underlying bedrock surface. Much of the sediment probably was derived from Pescadero Creek, a large coastal watershed that enters the Pacific Ocean about $3 \mathrm{~km}$ north of the Pigeon Point to southern Monterey Bay regional map area (see Maps C, D on sheet 9). The Pigeon Point shelf domain is transitional to the Pacifica-Pescadero shelf domain just north of it (see Watt and others, 2014).

Eittreim and others (2002, their fig. 15) showed an uppermost Pleistocene and Holocene sediment-thickness map that covers part of the area shown in Maps C and D on sheet 9 (from Point Año Nuevo in the north to Marina in the south). Their map combines three older investigations that cover the 
Davenport shelf (Mullins and others, 1985), Monterey Bay (Greene, 1977), and south-central Monterey Bay (Chin and others, 1988). These three investigations relied on analog seismic-reflection data collected in the 1970s and early 1980s, and they predate the availability of both digital high-resolution seismic-reflection data (see sheet 8) and high-resolution bathymetry (see, for example, see sheets 1,2), both of which provided essential input to the development of the maps shown on sheet 9 . Although the sediment-depth and -thickness patterns are grossly similar between the two generations of maps, the accuracy and level of detail in the newer maps is significantly higher.

Table 7-1. Area, sediment-thickness, and sediment-volume data for California's State Waters in the Pigeon Point to southern Monterey Bay region (domains 1-6), as well as in Offshore of Aptos map area.

\begin{tabular}{|c|c|c|c|}
\hline \multicolumn{4}{|c|}{ Regional sediment-thickness domains in Pigeon Point to southern Monterey Bay region } \\
\hline & Area $\left(\mathrm{km}^{2}\right)$ & $\begin{array}{c}\text { Mean sediment } \\
\text { thickness }(\mathrm{m})\end{array}$ & $\begin{array}{c}\text { Sediment volume } \\
\left(106 \mathrm{~m}^{3}\right)\end{array}$ \\
\hline Entire Pigeon Point to southern Monterey Bay region & 849 & 6.7 & 5,708 \\
\hline (1) Southern Monterey Bay & 253 & 6.2 & 1,555 \\
\hline (2) Northern Monterey Bay & 307 & 6.7 & 2,065 \\
\hline (3) Davenport shelf & 134 & 8.3 & 1,113 \\
\hline (4) Waddell Creek delta & 29 & 7.8 & 224 \\
\hline (5) Año Nuevo shelf & 58 & 2.6 & 154 \\
\hline (6) Pigeon Point shelf & 68 & 8.8 & 598 \\
\hline \multicolumn{4}{|c|}{ Sediment thickness in Offshore of Aptos map area } \\
\hline Northern Monterey Bay & 167 & 7.4 & 1,241 \\
\hline
\end{tabular}




\title{
Chapter 8. Geologic and Geomorphic Map of the Offshore of Aptos Map Area (Sheet 10)
}

\author{
By Samuel Y. Johnson, Stephen R. Hartwell, Clifton W. Davenport, and Katherine L. Maier
}

\section{Geologic and Geomorphic Summary}

Marine geology and geomorphology were mapped in the Offshore of Aptos map area, extending seaward from approximate Mean High Water (MHW). MHW is defined at an elevation of $1.46 \mathrm{~m}$ above the North American Vertical Datum of 1988 (NAVD 88) (Weber and others, 2005). Offshore geologic units were delineated on the basis of integrated analyses of adjacent onshore geology with multibeam bathymetry and backscatter imagery (sheets 1,2,3), seafloor-sediment and rock samples (Reid and others, 2006), digital camera and video imagery (sheet 6), and high-resolution seismic-reflection profiles (sheet 8). Aerial photographs taken in multiple years were used to map the nearshore area (0 to $10 \mathrm{~m}$ water depth) and to link the offshore and onshore geology. The relative proportions of all offshore map units are shown in table 8-1.

The onshore geology was compiled from Brabb (1997) and Wagner and others (2002); unit ages, which are from these sources, reflect local stratigraphic relations. In addition, some Quaternary units were modified by C.W. Davenport on the basis of analysis of 2009 lidar imagery.

Most of the offshore part of the map area occupies very gently dipping (about $0.1^{\circ}$ to $0.4^{\circ}$ ) continental shelf, extending from the nearshore to water depths of about $70 \mathrm{~m}$. In the southwestern part of the map area, the shelf is incised by the north-trending head of Soquel Canyon, which has a maximum depth of $260 \mathrm{~m}$ on the south edge of the map. The shelf is underlain by upper Neogene bedrock and a variably thick (as much as $32 \mathrm{~m}$ ) upper Quaternary sediment cover (see sheet 9). Sea level has risen 120 to $130 \mathrm{~m}$ during about the last 21,000 years (for example, Stanford and others, 2011), leading to broadening of the continental shelf, progressive eastward migration of the shoreline and wave-cut platform, and associated transgressive erosion and deposition of sediment. Sea-level rise was apparently not steady during this period, leading to development of shoreline angles and adjacent submerged wavecut platforms and risers (Kern, 1977). These features commonly are removed by erosion or buried by shelf sediment, however, their original morphology is at least partly preserved along the rim of Soquel Canyon. Geologic map units include three wave-cut platforms (units Qwp1, Qwp2, Qwp3) and risers (units Qwpr1, Qwpr2, Qwpr3), separated by shoreline angles at depths of about 96 to $100 \mathrm{~m}, 108 \mathrm{~m}$, and 120 to $125 \mathrm{~m}$. The deepest paleoshoreline (about $120 \mathrm{~m}$ deep) approximately corresponds to sea level during the final stages of the last sea-level lowstand (Stanford and others, 2011). Submergence during sea-level rise also cut off the direct connection between Soquel Canyon and coastal watersheds, rendering the submarine canyon relatively inactive. Although slightly sheltered by the headlands of northern Monterey Bay, the Offshore of Aptos map area is now subject to significant wave energy and strong currents.

Shelf morphology and geology are also affected by local faulting, folding, and uplift. The shelf in the Offshore of Aptos map area is cut by a diffuse zone of northwest-striking, steeply dipping to vertical faults mapped with high-resolution, seismic-reflection profiles (sheet 8). Faults are mapped on the basis of truncation or warping of reflections and (or) juxtaposition of reflection panels with different seismic parameters. Seismic profiles traversing this diffuse zone cross as many as 13 faults over a distance of $8 \mathrm{~km}$ (see, for example, fig. 3, sheet 8). Mapped fault lengths in this diffuse zone are typically 2 to $7 \mathrm{~km}$, and the strike of these offshore faults ranges from about $325^{\circ}$ to $350^{\circ}$ from southwest to northeast. Faults in this diffuse zone cut through Neogene bedrock and locally appear to disrupt overlying upper Quaternary sediments; the presence of warped reflections along some fault strands suggests there may be both vertical and strike-slip offsets. This broad, distributed zone of 
deformation resembles the northwest-trending Monterey Bay Fault Zone (Greene, 1977, 1990), located about $10 \mathrm{~km}$ west in outer Monterey Bay, which similarly lacks a lengthy continuous "master fault." Deformation in both the Monterey Bay Fault Zone and the diffuse zone of faults in the Offshore of Aptos map area is attributable to their location in the 40-km-wide, northward-narrowing structural zone between two major right-lateral strike-slip fault zones - the San Andreas Fault Zone to the east and the San Gregorio Fault Zone to the west (fig. 1-1) (McCulloch, 1987; Brabb, 1997; Wagner and others, 2002; Dickinson and others, 2005).

Emergent late Pleistocene marine terraces on the south flank of the Santa Cruz Mountains in and north of northeastern Monterey Bay are as high as $125 \mathrm{~m}$. Anderson and Menking (1994) report a 50- to 60-m elevation for the shoreline angle tied to the lowest emergent terrace (assigned to oxygen isotope stage $5 \mathrm{c}$ or $5 \mathrm{e}$ ) in the Aptos vicinity, suggesting an uplift rate of about 0.4 to $0.6 \mathrm{~mm} / \mathrm{yr}$. Anderson (1990) and Anderson and Menking (1994) attributed this uplift to advection of crust around a bend in the San Andreas Fault, which lies $13 \mathrm{~km}$ northeast of the Aptos shoreline. The uplifted region in this tectonic model would include the nearshore and shelf of northeastern Monterey Bay, however offshore uplift rates are not constrained.

From west La Selva Beach to the western edge of the map area, the upper Miocene and Pliocene Purisima Formation (unit Tp; Powell and others, 2007) forms discontinuous outcrops that extend from coastal bluffs into the offshore to depths as great as $25 \mathrm{~m}$. The seafloor outcrops are most prominent offshore of Soquel Point and have relatively low relief, which is most likely a result of low structural dips. The Purisima Formation also forms outcrops in the steep walls of the head of Soquel Canyon. Other "hard" bottom in the map area is mapped at the location of a wastewater outfall pipe offshore of the mouth of the Pajaro River (artificial fill, unit af).

Coarser grained sands and gravels (units Qmsc and Qmsd) are primarily recognized on the basis of bathymetry and high backscatter (sheets 1,2,3). Unit Qmsc occurs only adjacent to bedrock at Soquel Point in water depths less than $20 \mathrm{~m}$. Unit Qmsd forms erosional lags in scoured depressions at water depths ranging from about 10 to $25 \mathrm{~m}$. The Qmsd depressions have irregular to lenticular outlines; are a few tens of centimeters deep; range in size from a few tens of square meters to as much as $54,000 \mathrm{~m}^{2}$; and are either bounded by relatively sharp and less commonly diffuse contacts with unit Qms sands, or by abrupt contacts with seafloor bedrock outcrops. Qmsd depressions are most abundant in a northeast-trending zone between Seacliff State Beach and La Selva Beach, where they form distinct, narrow $(<50 \mathrm{~m})$ linear bands that extend about $4 \mathrm{~km}$ offshore.

Scour depressions similar to those mapped adjacent to bedrock near Soquel Point are common along this stretch of the California coast (Hallenbeck and others, 2012; Davis and others, 2013). Such features have been referred to as "rippled-scour depressions" (Cacchione and others, 1984) or "sorted bedforms" (Goff and others, 2005; Trembanis and Hume, 2011). They form where surficial offshore sandy sediment is relatively thin (thus unable to fill the depressions) owing to both low sediment supply and to erosion and transport of sediment during large ocean swells. The elongate, linear, shore-normal bands of small scour depressions between Aptos and La Selva Beach are morphologically unique and comparable occurrences have not been recognized elsewhere along the California coast. Although the general areas in which both unit Qmsd scour depressions and surrounding Qms sand sheets occur are not likely to change substantially, the boundaries of the unit(s) are likely ephemeral, changing seasonally and during significant storm events.

An offshore transition from unit Qms to finer grained marine sediments of unit Qmsf is present at water depths of 25 to $30 \mathrm{~m}$. Unit Qmsf commonly is extensively bioturbated and primarily consists of mud and muddy sand. Edwards (2002) and Grossman and others (2006) suggested that these finer grained sediments form an extensive "mid-shelf mud belt" that is sourced primarily by the San Lorenzo River, Pajaro River, and smaller coastal watersheds. 
Modern nearshore and inner shelf to midshelf sediments are mostly sand (unit Qms) and a mix of sand and gravel (units Qmsc and Qmsd). There is an extensive area in northeastern Monterey Bay (northwestern part of the map area) where unit Tp bedrock is overlain by a very thin cover of Qms; such areas are mapped and labeled as composite units (Qms/Tp) and are shown with a white-stippled pattern on the map. In addition, a small area near the head of Soquel Canyon (southwestern part of the map area) is overlain by a thin cover of Qmsf; this area, which is labeled as composite unit Qmsf/Tp, is shown on the map with a gray-stippled pattern. Storlazzi and others (2011) showed that active sediment transport in the nearshore of northern Monterey Bay can lead to significant burial and exhumation of offshore bedrock reefs, and it is likely that the sediment cover in the mapped composite areas is ephemeral and transient.

A $4.3 \mathrm{~km}^{2}$ zone of hummocky seafloor (Qmsh) surrounded by fine-grained Qmsf occurs in the southeastern part of the map area at 30 to $35 \mathrm{~m}$ water depth, about 3 to $4 \mathrm{~km}$ north of the head of Soquel Canyon. Bathymetric contours reveal that the hummocky zone has an embayed up-slope margin, and relief on individual hummocks within the zone is as much as $100 \mathrm{~cm}$ over a lateral distance of $100 \mathrm{~m}$. The hummocky zone probably resulted from liquefaction, and associated induced ground failure forced by strong ground motions from earthquakes. The embayed upper margin of the zone also indicates some slumping, surprising given the extremely gentle dip of the shelf (about $0.2^{\circ}$ ) at this location. Earthquake sources capable of generating strong ground motions at this location could include the distributed fault zone in northeastern Monterey Bay (several mapped faults cut through the hummocky area; see fig. 3 on sheet 8 ) or the nearby San Andreas Fault (20 km to the northeast) or San Gregorio Fault (19 km to the southwest). Recent large earthquakes on the San Andreas Fault include the M6.9 1989 Loma Prieta earthquake and the M7.8 1906 Great California earthquake (Northern California Earthquake Data Center, 2014).

Soquel Canyon is a tributary to the much larger Monterey Canyon system (Greene and others, 2002). The canyon axis plunges south about $4^{\circ}$; side-canyon walls generally dip about $5^{\circ}$ but are locally as steep as $20^{\circ}$ to $25^{\circ}$. Non-bedrock geologic units in Soquel Canyon are largely defined and delineated on the basis of geomorphology. Unit Qcw represents mud and sand draped over the upper submarine canyon wall. Unit Qcfa represents the mainly mud fill of the inactive axial canyon channel. 
Table 8-1. Areas and relative proportions of offshore geologic map units in Offshore of Aptos map area.

\begin{tabular}{|c|c|c|c|}
\hline Map Unit & Area $\left(m^{2}\right)$ & Area $\left(\mathrm{km}^{2}\right)$ & Percent of total area \\
\hline \multicolumn{4}{|c|}{ Marine sedimentary units } \\
\hline af & 52,122 & 0.1 & 0.0 \\
\hline Qms & $92,185,232$ & 92.2 & 48.2 \\
\hline Qmsd & $1,056,856$ & 1.1 & 0.6 \\
\hline Qmsc & 228,048 & 0.2 & 0.1 \\
\hline Qmsf & $74,289,989$ & 74.3 & 38.8 \\
\hline Qmsh & $4,306,518$ & 4.3 & 2.3 \\
\hline Qcw & $2,739,430$ & 2.7 & 1.4 \\
\hline Qcfa2 & 65,031 & 0.1 & 0.0 \\
\hline Qwp3 & 85,767 & 0.1 & 0.0 \\
\hline Qwpr3 & 13,482 & 0.0 & 0.0 \\
\hline Qwp2 & 13,529 & 0.0 & 0.0 \\
\hline Qwpr2 & 7,897 & 0.0 & 0.0 \\
\hline Qwp1 & 8,767 & 0.0 & 0.0 \\
\hline Qwpr1 & 11,229 & 0.0 & 0.0 \\
\hline Total, sedimentary units & $175,063,896$ & 175.1 & 91.5 \\
\hline \multicolumn{4}{|c|}{ Bedrock units } \\
\hline Qms/Tp & $11,446,945$ & 11.4 & 6.0 \\
\hline Qmsf/Tp & 255,331 & 0.3 & 0.1 \\
\hline Tp & $4,543,107$ & 4.5 & 2.4 \\
\hline Total, bedrock units & $16,245,383$ & 16.2 & 8.5 \\
\hline Total, Offshore of Aptos map area & $191,309,279$ & 191.3 & 100.0 \\
\hline
\end{tabular}




\section{DESCRIPTION OF MAP UNITS}

\section{OFFSHORE GEOLOGIC AND GEOMORPHIC UNITS}

[Note that, where older units (typically, bedrock) are overlain by thin $(<1 \mathrm{~m}$ thick) unconsolidated Quaternary deposits, composite units are mapped. These composite units, which are shown with gray or white stipple pattern on older unit, are designated by composite label indicating both overlying sediment cover and lower (older) unit, separated by slash (for example, Qms/Tp indicates that thin sheet of Qms overlies Tp)]

af Artificial fill (late Holocene) - Wastewater outfall pipe offshore of the mouth of the Pajaro River

Qms Marine nearshore and shelf deposits (late Holocene)—Predominantly sand; ripple marks common

Qmsc Coarse-grained marine nearshore and shelf deposits (late Holocene)—Mostly coarse sand and gravel

Qmsf Fine-grained marine shelf deposits (late Holocene)—Predominantly mud, very fine sand, and silt; commonly bioturbated; found on gently seaward-dipping (less than $0.5^{\circ}$ ) surfaces at depths greater than about 25 to $30 \mathrm{~m}$

Qmsd Marine shelf scour depressions (late Holocene) - Inferred to be coarse sand and possibly gravel. Found as (1) distinct, narrow $(<50 \mathrm{~m})$, linear bands that extend about $4 \mathrm{~km}$ offshore in a northeast-trending zone between Seacliff State Beach and La Selva Beach; and (2) adjacent to and (or) offshore of bedrock outcrops near Soquel Point, forming single depressions or groups of depressions interspersed with elevated shelf sediments (unit Qms). Depressions typically have curved to irregular margins and diffuse to sharp boundaries, and typically are 15 to $50 \mathrm{~cm}$ deep. In map area, backscatter data show intensity contrasts that suggest depressions are filled with sediment that is coarser than intervening elevated sandy shelf deposits. General area in which unit is found is not likely to change substantially, but boundaries of unit(s) and locations of individual depressions (and intervening flat sheets) likely are ephemeral, changing during significant storm events

Qmsh Marine shelf hummocky seafloor (late Holocene)—Zone of hummocky seafloor on midshelf, probably formed by liquefaction and slumping

Qcw Submarine canyon wall deposits (late Holocene)_Fine-grained sediment draping walls in upper Soquel Canyon

Qcfa Submarine canyon axial channel deposits (late Holocene)_Fine-grained sediment fill of inactive axial channel of upper Soquel Canyon

Qwp3 Submerged wave-cut platform, about 96 to $100 \mathrm{~m}$ deep (late Pleistocene) — Inferred to be sand and gravel. Present only on the west flank of the head of Soquel Canyon. Platform is as wide as $225 \mathrm{~m}$ and can be traced laterally for about $570 \mathrm{~m}$; bounded upslope by paleoshoreline angle (Kern, 1977) and unit Qwpr3. Platform is shallowest and youngest of three platforms inferred to have been formed by wavecutting in periods of relative sea-level stillstands during overall sea-level rise following Last Glacial Maximum (Stanford and others, 2011)

Qwpr3 Submerged wave-cut platform riser, base about 96 to $100 \mathrm{~m}$ deep (late Pleistocene)Inferred to be sand and gravel, may be draped with fine-grained sediment. Smooth, offshore-dipping surface as wide as $50 \mathrm{~m}$; upper contact is continental shelf, whereas lower contact is paleoshoreline angle (Kern, 1977). Riser represents paleo-sea cliff or onshore slope associated with development of wave-cut platform of unit Qwp3 
Qwp2 Submerged wave-cut platform, about $108 \mathrm{~m}$ deep (late Pleistocene)—Inferred to be sand and gravel, may be draped with fine-grained sediment. Present only on the west flank of the head of Soquel Canyon. Platform is as wide as $200 \mathrm{~m}$, dips gently offshore, and can be traced laterally for about $165 \mathrm{~m}$; bounded upslope by paleoshoreline angle (Kern, 1977) and unit Qwpr2. This platform is the second of three wave-cut platforms inferred to have been formed by wavecutting in periods of relative sea-level stillstands during overall sea-level rise following the Last Glacial Maximum (Stanford and others, 2011)

Qwpr2 Submerged wave-cut platform riser, base about $108 \mathrm{~m}$ deep (late Pleistocene)—Inferred to be sand and gravel; may be draped with fine-grained sediment. Smooth offshoredipping surface, as wide as about $25 \mathrm{~m}$; lower contact is paleoshoreline angle (Kern, 1977). Riser represents paleo-sea cliff or onshore slope associated with development of wave-cut platform of unit Qwp2

Qwp1 Submerged wave-cut platform, about 120 to $125 \mathrm{~m}$ deep (late Pleistocene) - Inferred to be sand and gravel; may be draped with fine-grained sediment. Present only on the west flank of the head of Soquel Canyon. Platform is as wide as $40 \mathrm{~m}$, dips gently offshore, and can be traced laterally for as much as $125 \mathrm{~m}$; bounded upslope by paleoshoreline angle (Kern, 1977) and unit Qwpr1. Platform is deepest and oldest of three platforms inferred to have been formed by wavecutting in periods of relative sea-level stillstands during overall sea-level rise following the Last Glacial Maximum (Stanford and others, 2011)

Qwpr1 Submerged wave-cut platform riser, base about 120 to $125 \mathrm{~m}$ deep (late Pleistocene) Inferred to be sand and gravel; may be draped with fine-grained sediment. Smooth offshore-dipping surface, as wide as about $35 \mathrm{~m}$; lower contact is paleoshoreline angle (Kern, 1977). Riser represents paleo-sea cliff or onshore slope associated with development of wave-cut platform of unit Qwp1

Tp Purisima Formation (Pliocene and late Miocene) — Predominantly gray and greenish-gray to buff, fine-grained marine sandstone, siltstone, and mudstone. Stippled areas (composite units Qms/Tp and Qmsf/Tp) indicate where thin sheets of Qms or Qmsf overlie unit

\section{ONSHORE GEOLOGIC AND GEOMORPHIC UNITS}

[Units are compiled from Brabb (1997) and Wagner and others (2002)]

af

Qc

Qbs

Qa

Qf

$\mathrm{Qb}$

Artificial fill (late Holocene) - Material placed by humans

Stream-channel deposits (late Holocene) — Sand and gravel deposits within active stream channel

Beach sand deposits (late Holocene) - Fine to very coarse sand that forms active beaches in coastal environments; may form a veneer over bedrock platform. Locally can include dune sands that are too small to be mapped at this scale

Alluvial deposits (late Holocene) - Alluvium deposited within the immediate vicinity of active stream channel; mapped where geomorphic expression indicates active stream channel but in-channel deposits cannot be delineated at map scale

Alluvial fan deposits (late Holocene) - Alluvial fan deposits judged to be latest Holocene $(<1,000$ years) in age, based on records of historical inundation, location with respect to older fans, or presence of youthful braid bars and distributary channels

Basin deposits (Holocene) - Unconsolidated fine-grained sediment deposited in low-energy environments including estuaries, lagoons, marsh-filled sloughs, and lakes 
Qds Dune sand (Holocene) — Very well-sorted, fine to medium sand that forms both active dunes and stabilized dunes in coastal environments

Qt Stream-terrace deposits (Holocene) — Relatively smooth and undissected, relatively lowlying terraces adjacent to lower reaches of active stream channels

Qya Alluvial deposits, undivided (Holocene) - Alluvium deposited adjacent to active stream channels. Locally may include small marine-terraces and channel deposits where such features are too small to delineate at map scale

Qyf Alluvial fan deposits (Holocene) - Relatively undissected, unconsolidated, heterogeneous layers of sand, silt, and gravel deposited by streams emanating from canyons onto alluvial plains. Deposits are identified primarily by fan morphology and topographic expression

Qyt Stream-terrace deposits (Holocene) - Mapped where relatively smooth, undissected, relatively low-lying terraces exist adjacent to and elevated above active stream channels

Qcl Colluvium (Holocene) - Loose to firm, unsorted sand, silt, clay, gravel, rock debris, and organic material in varying proportions; typically mapped in hillside swales and narrow immature drainages; can contain numerous small landslides and (or) alluvial fans

Qoa Alluvial deposits, undivided (Holocene and late Pleistocene)—Mapped on gently sloping to level terrace surfaces adjacent to stream channels where relative age is uncertain or separate units could not be delineated at map scale

Qot2 Stream-terrace deposits (Holocene and late Pleistocene) - Sand, gravel, silt, and minor clay of uncertain age; underlies relatively flat platforms elevated above stream channels

QIs Landslide deposits (Holocene and Pleistocene)—Weathered and disintegrated rocks and soil; mapped units range from deep-seated landslides to active colluvium

Qof2 Alluvial fan deposits (Pleistocene) - Mapped where Pleistocene age is indicated by greater dissection than is present on Holocene fans, or the geomorphic feature lies at elevations higher than those of adjacent Holocene fans

Qtw

Qof1

Qmt2

Terrace Deposits of Watsonville terrace (Pleistocene)-Undivided fluvial and alluvial fan facies of semiconsolidated, moderately to poorly sorted silt, sand, clay, and gravel

Alluvial fan deposits (Pleistocene) - Discontinuous deposits of semiconsolidated, moderately to poorly sorted layers of silty clay, silt, sand, and gravel deposited by streams, sheet flow, and debris flow adjacent to mountains

Qmt1 Marine terrace deposits, undivided (Pleistocene)—Semiconsolidated sand and less common gravel deposits on uplifted marine abrasion platforms along the coast; locally may include fluvial and (or) colluvial deposits that are too small or numerous to map at scale; found at elevations higher than those of Qmt2

Qes Eolian deposits of Sunset Beach (Pleistocene) - Weakly consolidated, well-sorted fine- to medium-grained sand. Forms extensive coastal dune field

Qem Eolian deposits of Manresa Beach (Pleistocene) - Weakly to moderately consolidated, moderately well-sorted silt and sand. Deposited in extensive coastal dune field

Qar Aromas Sand, undivided (Pleistocene) - Heterogeneous unit of mainly eolian and fluvial sand, silt, clay, and gravel 
Qae Eolian lithofacies of Aromas Sand (Pleistocene)_-Moderately well-sorted eolian sand

Qaf Fluvial lithofacies of Aromas Sand (Pleistocene)-Semiconsolidated, moderately- to poorly-sorted materials deposited by meandering and braided streams

Qot1 Older terrace deposits (Pleistocene) - Stream deposits underlying flat-topped ridges with trends parallel to stream course

QTu Continental deposits, undivided (Pleistocene and Pliocene[?]) — Semiconsolidated, finegrained, oxidized sand and silt. May represent highly weathered eolian sediments deposited on Purisima Formation

Tp Purisima Formation (Pliocene and late Miocene) — Thick-bedded yellow-gray tuffaceous and diatomaceous siltstone with thick interbeds of blueish-gray fine-grained andesitic sandstone. Locally highly fossiliferous

Tsm Santa Margarita Sandstone (late Miocene)_Friable, yellowish-gray to white, medium- to fine-grained arkosic sandstone; locally calcareous and bituminous; base of section has local pebble conglomerate 


\section{Acknowledgments}

This publication was funded by the California Ocean Protection Council and the U.S. Geological Survey (USGS) Coastal and Marine Geology Program. We thank Hilde Schwartz (University of California, Santa Cruz) and Steve Watt (U.S. Geological Survey) for their constructive reviews. We are very grateful to USGS editor Taryn Lindquist for helping us develop the templates and formats for this series of publications, and for invaluable editorial review and suggestions. 


\section{References Cited}

Ainley, D.B., and Hyrenbach, K.D., 2010, Top-down and bottom-up factors affecting seabird population trends in the California current system (1985-2006): Progress in Oceanography, v. 84, p. 242-254.

Anderson, R.S., 1990, Evolution of the northern Santa Cruz Mountains by advection of crust past a San Andreas Fault bend: Science, v. 249, p. 397-401.

Anderson, T.J., Cochrane, G.R., Roberts, D.A., Chezar, H., and Hatcher, G., 2007, A rapid method to characterize seabed habitats and associated macro-organisms, in Todd, B.J., and Greene, H.G., eds., Mapping the seafloor for habitat characterization: Geological Association of Canada Special Paper 47, p. 71-79.

Anderson, R.S., and Menking, K.M., 1994, The Quaternary marine terraces of Santa Cruz, CaliforniaEvidence for coseismic uplift on two faults: Geological Society of America Bulletin, v. 106, p. 649664.Best, T.C., and Griggs, G.B., 1991, A sediment budget for the Santa Cruz littoral cell, in Osborne, R.H., From shoreline to the abyss: Society of Economic Paleontologists and Mineralogists, v. 46, p. 35-50.

Brabb, E.E., 1997, Geologic map of Santa Cruz County, California-A digital database: U.S. Geological Survey Open-File Report 97-489, scale 1:62,500, available at http://pubs.usgs.gov/of/1997/of97-489/. Briggs, J.C., 1974, Marine zoogeography: New York, McGraw-Hill, 480 p.

Cacchione, D.A., Drake, D.E., Grant, W.D., and Tate, G.B., 1984, Rippled scour depressions of the inner continental shelf off central California: Journal of Sedimentary Petrology, v. 54, p. 1,280-1,291.

Calambokidis, J., and Barlow, J., 2004, Abundance of blue and humpback whales in the eastern North Pacific estimated by capture-recapture and line-transect methods: Marine Mammal Science, v. 20, p. 63-85.

California Department of Fish and Wildlife, 2008, California Marine Life Protection Act master plan for marine protected areas-Revised draft: California Department of Fish and Wildlife [formerly California Department of Fish and Game], available at https://www.wildlife.ca.gov/Conservation/Marine/MPAs/Master-Plan.

Caress, D.W., Chayes, D.N., and Ferreira, C.D.S., 2015, MB-System seafloor mapping software, available at http://www.ldeo.columbia.edu/res/pi/MB-System/.

Catuneanu, O., 2006, Principles of sequence stratigraphy: Amsterdam, Elsevier, 375 p.

Chin, J.L., Clifton, H.E., and Mullins, H.T., 1988, Seismic stratigraphy and late Quaternary shelf history, south-central Monterey Bay, California: Marine Geology, v. 81, p. 137-157.

Cochrane, G.R., 2008, Video-supervised classification of sonar data for mapping seafloor habitat, in Reynolds, J.R., and Greene, H.G., eds., Marine habitat mapping technology for Alaska: Fairbanks, University of Alaska, Alaska Sea Grant College Program, p. 185-194, available at http://doc.nprb.org/web/research/research\%20pubs/615_habitat_mapping_workshop/Individual\%20C hapters\%20High-Res/Ch13\%20Cochrane.pdf.

Cochrane, G.R., Conrad, J.E., Reid, J.A., Fangman, S., and Golden, N., 2005, Nearshore benthic habitat GIS for the Channel Islands National Marine Sanctuary and southern California state fisheries reserves, volume II: U.S. Geological Survey Open-File Report 2005-1170, available at http://pubs.usgs.gov/of/2005/1170/.

Cochrane, G.R., and Lafferty, K.D., 2002, Use of acoustic classification of sidescan sonar data for mapping benthic habitat in the Northern Channel Islands, California: Continental Shelf Research, v. 22, p. 683-690.

Cochrane, G.R., Nasby, N.M., Reid, J.A., Waltenberger, B., and Lee, K.M., 2003, Nearshore benthic habitat GIS for the Channel Islands National Marine Sanctuary and southern California state fisheries reserves, volume 1: U.S. Geological Survey Open-File Report 03-85, available at http://pubs.usgs.gov/of/2003/0085/. 
Collins, C.A., Garfield, N., Rago, T.A., Rischmiller, F.W., and Carter, E., 2000, Mean structure of the inshore counter-current and California undercurrent off Point Sur, California: Deep-Sea Research II, v. 47, p. 765-782.

Davis, A.C.D., Kvitek, R.G., Mueller, C.B.A., Young, M.A., Storlazzi, C.D., and Phillips, E.L., 2013, Distribution and abundance of rippled scour depressions along the California coast: Continental Shelf Research, v. 69, p. 88-100, doi:10.1016/j.csr.2013.09.010.

Dawson, M.N., Waples, R.S., and Bernardi, G., 2006, Phylogeography, in Allen, L.G., Pondella, D.J., II, and Horn, M.H., eds., The ecology of marine fishes, California and adjacent waters: Berkeley, University of California Press, $660 \mathrm{p}$.

Dickinson, W.R., 2004, Evolution of the North American cordillera: Annual Reviews of Earth and Planetary Sciences, v. 32, p. 13-45.

Dickinson, W.R., Ducea, M., Rosenberg, L.I., Greene, H.G., Graham, S.A., Clark, J.C., Weber, G.E., Kidder, S., Ernst, W.G., and Brabb, E.E., 2005, Net dextral slip, Neogene San Gregorio-Hosgri fault zone, coastal California-Geologic evidence and tectonic implications: Geological Society of America Special Paper 391, 43 p.

Edwards, B.D., 2002, Variations in sediment texture on the northern Monterey Bay National Marine Sanctuary continental shelf: Marine Geology, v. 181, p. 83-100.

Eittreim, S.L., Anima, R.J., and Stevenson, A.J., 2002, Seafloor geology of the Monterey Bay area continental shelf: Marine Geology, v. 181, p. 3-34.

Fader, G.B.J., 1997, The effects of shallow gas on seismic reflection profiles, in Davies, T.A., Bell, T., Cooper, A.K., Josenhans, H., Polyak, L., Solheim, A., Stoker, M.S., and Stravers, J.A., eds., Glaciated continental margins - an atlas of acoustic images: London, Chapman and Hall, p. 29-30.

Goff, J.A., Mayer, L.A., Traykovski, P., Buynevich, I., Wilkens, R., Raymond, R., Glang, G., Evans, R.L., Olson, H., and Jenkins, C., 2005, Detailed investigations of sorted bedforms or "rippled scour depressions," within the Martha's Vineyard Coastal Observatory, Massachusetts: Continental Shelf Research, v. 25, p. 461-484, doi:10.1016/j.csr.2004.09.019.

Greene, H.G., 1977, Geology of the Monterey Bay region: U.S. Geological Survey Open-File Report 77-718, $347 \mathrm{p}$.

Greene, H.G., 1990, Regional tectonics and structural evolution of the Monterey Bay region, central California, in Garrison, R.E., Greene, H.G., Hicks, K.R., Weber, G.E., and Wright, T.L., eds., Geology and tectonics of the central California coastal region, San Francisco to Monterey: American Association of Petroleum Geologists, Pacific Section, Guidebook GB67, p. 31-56.

Greene, H.G., Bizzarro, J.J., O’Connell, V.M., and Brylinsky, C.K., 2007, Construction of digital potential marine benthic habitat maps using a coded classification scheme and its application, in Todd, B.J., and Greene, H.G., eds., Mapping the seafloor for habitat characterization: Geological Association of Canada Special Paper 47, p. 141-155.

Greene, H.G., Bizzarro, J.J., Tilden, J.E., Lopez, H.L., and Erdey, M.D., 2005, The benefits and pitfalls of geographic information systems in marine benthic habitat mapping, in Wright, D.J., and Scholz, A.J., eds., Place matters: Portland, Oregon State University Press, p. 34-46.

Greene, H.G., Maher, N.M., and Paull, C.K., 2002, Physiography of the Monterey Bay National Marine Sanctuary and implications about continental margin development: Marine Geology, v. 181, p. 55-82.

Greene, H.G., Yoklavich, M.M., Starr, R.M., O’Connell, V.M., Wakefield, W.W., Sullivan, D.E., McRea, J.E., and Cailliet, G.M., 1999, A classification scheme for deep seafloor habitats: Oceanologica Acta, v. 22, p. 663-678.

Griggs, G., Patsch, K., and Savoy, L., 2005, Living with the changing California Coast: Berkeley, University of California Press, 540 p. 
Grossman, E.E., Eittreim, S.L., Field, M.E., and Wong, F.L., 2006, Shallow stratigraphy and sedimentation history during high-frequency sea-level changes on the central California shelf: Continental Shelf Research, v. 26, p. 1,217-1,239, doi:10.1016/j.csr.2006.04.001.

Hallenbeck, T.R., Kvitek, R.G., and Lindholm, J., 2012, Rippled scour depressions add ecologically significant heterogeneity to soft-bottom habitats on the continental shelf: Marine Ecology Progress Series, v. 468, p. 119-133, doi:10.3354/meps09948.

Hanson, R.T., 2003, Geohydrologic framework of recharge and seawater intrusion in the Pajaro Valley, Santa Cruz and Monterey Counties, California: U.S. Geological Survey Water-Resources Investigation Report WRIR 03-4096, 88 p., available at http://pubs.water.usgs.gov/wrir034096/.

Hapke, C.J., Reid, D., Richmond, B.B., Ruggiero, P., and List, J., 2006, National assessment of shoreline change, part 3-Historical shoreline change and associated coastal land loss along sandy shorelines of the California coast: U.S. Geological Survey Open-File Report 2006-1219, 72 p., available at http://pubs.usgs.gov/of/2006/1219/.

Hovland, M., and Judd, A.G., 1988, Seabed pockmarks and seepages-Impact on geology, biology and the marine environment: London, Graham and Trotman, 293 p.

Inman, D.L., and Jenkins, D.A., 1999, Climate change and the episodicity of sediment flux of small California rivers: Journal of Geology, v. 107, p. 251-270.

Kern, J.P., 1977, Origin and history of upper Pleistocene marine terraces, San Diego, California: Geological Society of America Bulletin, v. 88, p. 1,553-1,566.

Koehl, M.A.R., and Wainwright, S.A., 1977, Mechanical adaptations of a giant kelp: Limnology and Oceanography, v. 22, p. 1,067-1,071.

Kvitek, R., Bretz, C., Cochrane, G.R., and Greene, H.G., 2006, Final report, Statewide Marine Mapping Planning Workshop, December 12-13, 2005, Seaside, Calif.: California State University, Monterey Bay, 108 p., available at http://euclase.csumb.edu/DATA_DOWNLOAD/StrategicMapgWrkshp05/MappingWorkshop12_1213/Final_Report/CA\%20Habitat\%20Mapping\%20Rpt.pdf.

Lynn, R.J., and Simpson, J.J., 1987, The California Current system-The seasonal variability of its physical characteristics: Journal of Geophysical Research, v. 92, p. 12,947-12,966.

Madden, C.J., Goodin, K.L., Allee, R., Finkbeiner, M., and Bamford, D.E., 2008, Draft Coastal and Marine Ecological Classification Standard: National Oceanic and Atmospheric Administration (NOAA) and NatureServe, v. III, 77 p.

McCulloch, D.S., 1987, Regional geology and hydrocarbon potential of offshore central California, in Scholl, D.W., Grantz, A., and Vedder, J.G., eds., Geology and resource potential of the continental Margin of western North America and Adjacent Oceans-Beaufort Sea to Baja California: CircumPacific Council for Energy and Mineral Resources, Earth Science Series, v. 6., p. 353-401.

McGowan, J.A., Cayan, D.R., and Korman, L.M., 1998, Climate-ocean variability and ecosystem response in the Northeast Pacific: Science, v. 281, p. 210-217.

Miller, K.A., and Estes, J.A., 1989, Western range extension for Nereocystis luetkeana in the North Pacific Ocean: Botanica Marina, v. 32, p. 535-538.

Mitchum, R.M., Jr., Vail, P.R., and Sangree, J.B., 1977, Seismic stratigraphy and global changes of sea level, part 6-Stratigraphic interpretation of seismic reflection patterns in depositional sequences, in Payton, C.E., ed., Seismic stratigraphy-Applications to hydrocarbon exploration: Tulsa, Okla., American Association of Petroleum Geologists Memoir 16, p. 117-134.

Mullins, H.T., Nagel, D.K., and Dominguez, L.L., 1985, Tectonic and eustatic controls of late Quaternary shelf sedimentation along the central California (Santa Cruz) continental margin-Highresolution seismic stratigraphic evidence: Sedimentary Geology, v. 45, p. 327-347. 
Murray, A.B., and Thieler, E.R., 2004, A new hypothesis and exploratory model for the formation of large-scale inner-shelf sediment sorting and "rippled scour depressions": Continental Shelf Research, v. 24, no. 3, p. 295-315, doi:10.1016/j.csr.2003.11.001.

National Centers for Environmental Information, 2015, Bathymetric data viewer and database, accessed October 10, 2015, at http://www.ngdc.noaa.gov/maps/bathymetry.

Northern California Earthquake Data Center, 2014, Northern California earthquake catalog: Northern California Earthquake Data Center database, accessed April 5, 2014, at http://www.ncedc.org/ncsn/.

Paull, C.K., Caress, D.W., Ussler III, W., Lundsten, E., and Meiner-Johnson, M., 2011, High-resolution bathymetry and the axial channels within Monterey and Soquel submarine canyons, offshore central California: Geosphere, v. 7, p. 1,077-1,101.

Petersen, M.D., Moschetti, M.P., Powers, P.M., Mueller, C.S., Haller, K.M., Frankel, A.D., Zeng, Yuehua, Rezaeian, Sanaz, Harmsen, S.C., Boyd, O.S., Field, Ned, Chen, Rui, Rukstales, K.S., Luco, Nico, Wheeler, R.L., Williams, R.A., and Olsen, A.H., 2014, Documentation for the 2014 update of the United States national seismic hazard maps: U.S. Geological Survey Open-File Report 2014-1091, 243 p., available at http://dx.doi.org/10.3133/ofr20141091.

Phillips, E.L., Storlazzi, C.D., Dartnell, P., and Edwards, B.D., 2007, Exploring rippled scour depressions offshore Huntington Beach, CA: Coastal Sediments 2007, v. 3, p. 1,851-1,864.

Powell, C.L., II, Barron, John J.A., Sarna-Wojcicki, A.M., Clark, J.C., Perry, F.A., Brabb, E.E., and Fleck, R.J., 2007, Age, stratigraphy, and correlations of the late Neogene Purisima Formation, central California Coast Ranges: U.S. Geological Survey Professional Paper 1740, 32 p., available at http://pubs.usgs.gov/pp/2007/1740/.

Reid, J.A., Reid, J.M., Jenkins, C.J., Zimmerman, M., Williams, S.J., and Field, M.E., 2006, usSEABED - Pacific Coast (California, Oregon, Washington) offshore surficial-sediment data release: U.S. Geological Survey Data Series 182, available at http://pubs.usgs.gov/ds/2006/182/.

Ritchie, A.C., Finlayson, D.P., and Logan, J.B., 2010, Swath bathymetry surveys of the Monterey Bay area from Point Año Nuevo to Moss Landing, San Mateo, Santa Cruz, and Monterey Counties, California: U.S. Geological Survey Data Series 514, available at http://pubs.usgs.gov/ds/514/.

Spalding, M.D., Fox, H.E., Allen, G.R., Davidson, N., Ferdana, Z.A., Finlayson, M., Halpern, B.S., Jorge, M.A., Lombana, A., Lourie, S.A., Martin, K.D., McManus, E., Molnar, J., Recchia, C.A., and Robertson, J., 2007, Marine ecoregions of the world-A bioregionalization of coastal and shelf areas: BioScience, v. 57, p. 573-583.

Spudich, P., ed., 1996, The Loma Prieta, California, earthquake of October 17, 1989-Main shock characteristics: U.S. Geological Survey Professional Paper 1550-A, 297 p., available at http://pubs.usgs.gov/pp/pp1550/pp1550a/.

Stanford, J.D., Hemingway, R., Rohling, E.J., Challenor, P.G., Medina-Elizalde, M., and Lester, A.J., 2011, Sea-level probability for the last deglaciation-A statistical analysis of far-field records: Global and Planetary Change, v. 79, p. 193-203, doi:10.1016/j.gloplacha.2010.11.002.

Stephens, J.S., Larson, R.J., and Pondella, D.J., II, 2006, Rocky reefs and kelp beds, in Allen, L.G., Pondella, D.J., II, and Horn, M.H., eds., The ecology of marine fishes, California and adjacent waters: Berkeley, University of California Press, 660 p.

Storlazzi, C.D., Fregoso, T.A., Golden, N.E., and Finlayson, D.P., 2011, Sediment dynamics and the burial and exhumation of bedrock reefs along an emergent coastline as elucidated by repetitive sonar surveys-Northern Monterey Bay, CA: Marine Geology, v. 289, p. 46-59.

Storlazzi, C.D., and Wingfield, D.K., 2005, Spatial and temporal variations in oceanographic and meteorologic forcing along the central California coast, 1980-2002: U.S. Geological Survey Scientific Investigations Report 2005-5085, 39 p., available at http://pubs.usgs.gov/sir/2005/5085/. 
Tinker, M.T., Doak, D.F., and Estes, J.A., 2008, Using demography and movement behavior to predict range expansion of the southern sea otter: Ecological Applications, v. 18, p. 1,781-1,794, doi:10.1890/07-0735.1.

Tissot, B.N., Yoklavich, M.M., Love, M.S., York, K., and Amend, M., 2006, Benthic invertebrates that form habitat on deep banks off southern California, with special reference to deep sea coral: Fishery Bulletin, v. 104, p. 167-181.

Trembanis, A.C., and Hume, T.M., 2011, Sorted bedforms on the inner shelf off northeastern New Zealand-Spatiotemporal relationships and potential paleo-environmental implications: Geo-Marine Letters, v. 31, p. 203-214, doi:10.1007/s00367-010-0225-8.

U.S. Geological Survey, 2009, National Archive of Marine Seismic Surveys: U.S. Geological Survey database, accessed April 5, 2011, at http://walrus.wr.usgs.gov/NAMSS/.

U.S. Geological Survey and California Geological Survey, 2010, Quaternary fault and fold database of the United States: U.S. Geological Survey database, accessed April 5, 2012, at http://earthquake.usgs.gov/hazards/qfaults/.

Waelbroeck, C., Labeyrie, L., Michel, E., Duplessy, J.C., McManus, J.F., Lambeck, K., Balbon, E., and Labracherie, M., 2002, Sea-level and deep water temperature changes derived from benthic foraminifera isotopic records: Quaternary Science Reviews, v. 21, p. 295-305.

Wagner, D.L., Greene, H.G., Saucedo, G.J., and Pridmore, C.L., 2002, Geologic map of the Monterey 30' $\times$ 60' quadrangle and adjacent areas, California: California Geological Survey Regional Geologic Map Series, scale 1:100,000, available at http://www.quake.ca.gov/gmaps/RGM/monterey/monterey.html.

Watt, J.T., Hartwell, S.R., Johnson, S.Y., Sliter, R.W., Phillips, E.L., Ross, S.L., and Chin, J.L., 2014, Local (Offshore of San Gregorio map area) and regional (offshore from Bolinas to Pescadero) shallow-subsurface geology and structure, California, sheet 9 in Cochrane, G.R., Dartnell, P., Greene, H.G., Watt, J.T., Golden, N.E., Endris, C.A., Phillips, E.L., Hartwell, S.R., Johnson, S.Y., Kvitek, R.G., Erdey, M.D., Bretz, C.K., Manson, M.W., Sliter, R.W., Ross, S.L., Dieter, B.E., and Chin, J.L. (G.R. Cochrane and S.A. Cochran, eds.), California State Waters Map Series-Offshore of San Gregorio, California: U.S. Geological Survey Scientific Investigations Map 3306, pamphlet 38 p., 10 sheets, scale 1:24,000, available at http://dx.doi.org/10.3133/sim3306.

Weber, G.E., 1990, Late Pleistocene slip rates on the San Gregorio fault zone at Point Año Nuevo, San Mateo County, California, in Greene, H.G., Weber, G.E., Wright, T.L., and Garrison, R.E., eds., Geology and tectonics of the central California coast region-San Francisco to Monterey: American Association of Petroleum Geologists, Pacific Section, volume and guidebook, v. 67, p. 193-204.

Weber, K.M., List, J.H., and Morgan, K.L.M., 2005, An operational mean high water datum for determination of shoreline position from topographic lidar data: U.S. Geological Survey Open-File Report 2005-1027, accessed April 5, 2011, at http://pubs.usgs.gov/of/2005/1027/.

Wentworth, C.K., 1922, A scale of grade and class terms for clastic sediments: Journal of Geology, v. 30, p. 377-392.

Wong, F.L., Phillips, E.L., Johnson, S.Y, and Sliter, R.W., 2012, Modeling of depth to base of Last Glacial Maximum and seafloor sediment thickness for the California State Waters Map Series, eastern Santa Barbara Channel, California: U.S. Geological Survey Open-File Report 2012-1161, 16 p., available at http://pubs.usgs.gov/of/2012/1161/.

Wright, D.J., Pendleton, M., Boulware, J., Walbridge, S., Gerlt, B., Eslinger, D., Sampson, D., and Huntley, E., 2012, ArcGIS Benthic Terrain Modeler (BTM), v. 3.0: Environmental Systems Research Institute and NOAA Coastal Services Center, Massachusetts Office of Coastal Zone Management, accessed February 1, 2013, at http://esriurl.com/5754. 